\title{
GEOLOGIA DA ÁREA NORDESTE DA FOLHA POÇO DA CRUZ, BACIA DE JATOBÁ, NORDESTE DO BRASIL
}

\author{
Pamela Caroline Silva de Sousa ${ }^{1}$ \\ Gelson Luís Fambrini ${ }^{2}$ \\ Renan Gustavo Barbosa Queiroz ${ }^{3}$ \\ Leonardo Marinho de Oliveira ${ }^{4}$ \\ 10.18190/1980-8208/estudosgeologicos.v30n1p45-78 \\ ${ }^{1}$ Graduado(a) em Geologia - UFPE, pamela.soousa@ hotmail.com \\ 2 Departamento de Geologia- UFPE, gelson.fambrini@ufpe.br \\ 3 Mestre em Geociências - UFPE, renanqueiroz88@ hotmail.com \\ ${ }^{4}$ Mestrando do Programa de Pós-Graduação em Geociências - UFPE, \\ leonardomarinho93@gmail.com
}

\section{RESUMO}

A Bacia de Jatobá está localizada na porção centro-sul do estado de Pernambuco e no norte da Bahia e Alagoas, possui uma área com cerca de $5000 \mathrm{~km}^{2}$, direção preferencial NE-SW e registro sedimentar com aproximadamente $3 \mathrm{~km}$. Esta bacia do tipo rifte foi desenvolvida a partir dos eventos distensivos da ruptura do supercontinente Gondwana e marca o limite norte do sistema rifte abortado Recôncavo-Tucano-Jatobá. A sucessão estratigráfica da área de estudo, localizada no distrito Campos, Ibimirim (PE), compõe as sequências Sinéclise, Início de Rifte e Clímax de Rifte da bacia. A partir da utilização de seções colunares e identificação de fácies sedimentares foram reconhecidas seis unidades estratigráficas, além de uma cobertura quaternária. As duas unidades flúvio-marinhas inferiores estão relacionadas aos registros sedimentares siluro-devonianos da sequência Sinéclise, enquanto os sedimentitos lacustres e fluvio-eólicos das unidades superiores marcam a sequência de Início de Rifte e Clímax de Rifte. A Formação Aliança, discutida de forma particular neste trabalho, representa os primeiros registros sedimentares da sequência de Início de Rifte de idade Neojurássica (andar Dom João). Essa unidade foi depositada sob um sistema lacustre, com níveis carbonáticos decimétricos altamente fossilíferos dispostos em espessos pacotes pelíticos, sugerindo deposição em momentos de variações energéticas de um lago raso. O detalhamento estratigráfico desses depósitos, associado a estudos petrográficos e paleontológicos, traz uma nova compreensão acerca do sistema deposicional que atuou nesse ambiente e os primeiros processos que deram início à abertura do rifte durante o Jurássico Superior.

Palavras Chave: Bacia de Jatobá, Pernambuco, Mapa Geológico, Rifte, Estratigrafia

\section{ABSTRACT}

The Jatobá Basin is located in the south-central portion of Pernambuco state and northern Bahia and Alagoas, it has an area of approximately $5000 \mathrm{~km}^{2}$ in a NE-SW preferred direction and sedimentary record has approximately $3 \mathrm{~km}$. It is a rift basin developed under extensional tectonic events related to the rupture of the Gondwana supercontinent and it marks the northern limit of the aborted Recôncavo-Tucano-Jatobá rift system. The stratigraphic succession in the Campos district, Ibimirim (PE), comprises the Syneclise sequence and Rift Initiation sequence as well as part of the Rift Climax sequence of the basin. Using columnar sections and identifying sedimentary facies, six stratigraphic units were recognized, in addition to the quaternary coverage. The two lower fluvial-marine units are related to the siluro-devonian sedimentary records of the Syneclise sequence, 
while fluvial-eolic and lacustrine sediments of the upper units mark the Rift Initiation and Rift Climax sequences. The Aliança Formation, discussed in a particular way in this paper, represents the first sedimentary records of the beginning of the Neojurassic rift (Dom João stage). Since it was deposited in a lacustrine system, this formation has highly fossiliferous decimetric carbonate levels arranged in thick pelitic packages, suggesting deposition during times of energy variations within a shallow lake. The detailing of the stratigraphy of these deposits, associated with petrographic and paleontological studies, brings a new understanding of the depositional system that occurred in this environment and the first processes that started the opening of the rift during the Upper Jurassic.

Keywords: Jatoba Basin, Pernambuco, Geological Map, Rift, Stratigraphy

\section{INTRODUÇÃO}

A Bacia de Jatobá tem sua maior porção no estado de Pernambuco, mas também ocupa áreas dos estados da Bahia e Alagoas. Possui uma área de cerca de $5000 \mathrm{~km}^{2}$, orientação principal NE-SW e um registro sedimentar que alcança a profundidade de $3 \mathrm{~km}$ (Costa $e t$ al., 2003). Seus limites estruturais são dados pela Falha de São Francisco à sul, que a separa da sub-bacia do Tucano Norte, e pela Falha de Ibimirim que controla seu depocentro (Magnavita \& Cupertino, 1987). É caracterizada como uma bacia do tipo rifte fazendo parte do sistema rifte abortado RecôncavoTucano-Jatobá. É formada por um hemigráben constituído predominantemente por blocos rota-cionados $\mathrm{e}$ progressivamente mais baixos com sentido a NW (Rocha, 2011). De acordo com Peraro (1995), a Bacia de Jatobá apresenta evolução tectônica relacionada com um regime transtensional.

Segundo Costa et al. (2007), falhas normais $\mathrm{N70E}$, sintéticas em relação à falha de borda, acomodam o mergulho das camadas a partir da margem flexural em direção ao depocentro. As principais feições estruturais da bacia são: a Falha de Ibimirim, o Graben de Ibimirim, o Horst do Icó e as falhas de Mata Verde e Moxotó (Aragão \& Peraro, 1994, Peraro 1995, Lima-Filho et al,. 2009, Rocha, 2011).

O objetivo deste trabalho é refinar os estudos acerca dessa região uma vez que a literatura geológica que trata da
Bacia do Jatobá é muito limitada (Veras et al., 2017); também pela necessidade de maiores conhecimentos da Estratigrafia regional e de detalhe da Formação Aliança que não se acha bem definida cartograficamente, cronoestratigraficamente, nem mesmo em termos de sua faciologia e sistemas deposicionais.

Este trabalho apresenta um levantamento geológico de uma área da região sententrional da Bacia de Jatobá, apresentando algumas das unidades que foram depositadas durante o rifte desde seu início e que afloram na região. Apresenta também um detalhamento estratigráfico de depósitos lacustres do início de rifte, associando a estudos petrográficos e paleontológicos, trazendo uma interpretação sobre a atuação dos sistemas deposicionais nesse ambiente.

\section{LOCALIZAÇÃO DA ÁREA}

A área de estudo localiza-se na Bacia de Jatobá, estado de Pernambuco, nordeste brasileiro, mais especificamente no extremo nordeste da Folha Poço da Cruz SC.24-X-A-VI (SUDENE 1969; Neumann et al., 2017), correspondente às coordenadas UTMWGS84 (654000, 9060000), (665000, 9054000), datum SIRGAS 2000, zona 24 L. A região estudada possui $11 \mathrm{Km}$ de extensão longitudinal e $6 \mathrm{Km}$ de extensão latitudinal, totalizando $66 \mathrm{~km}^{2}$ (Fig. 1) 

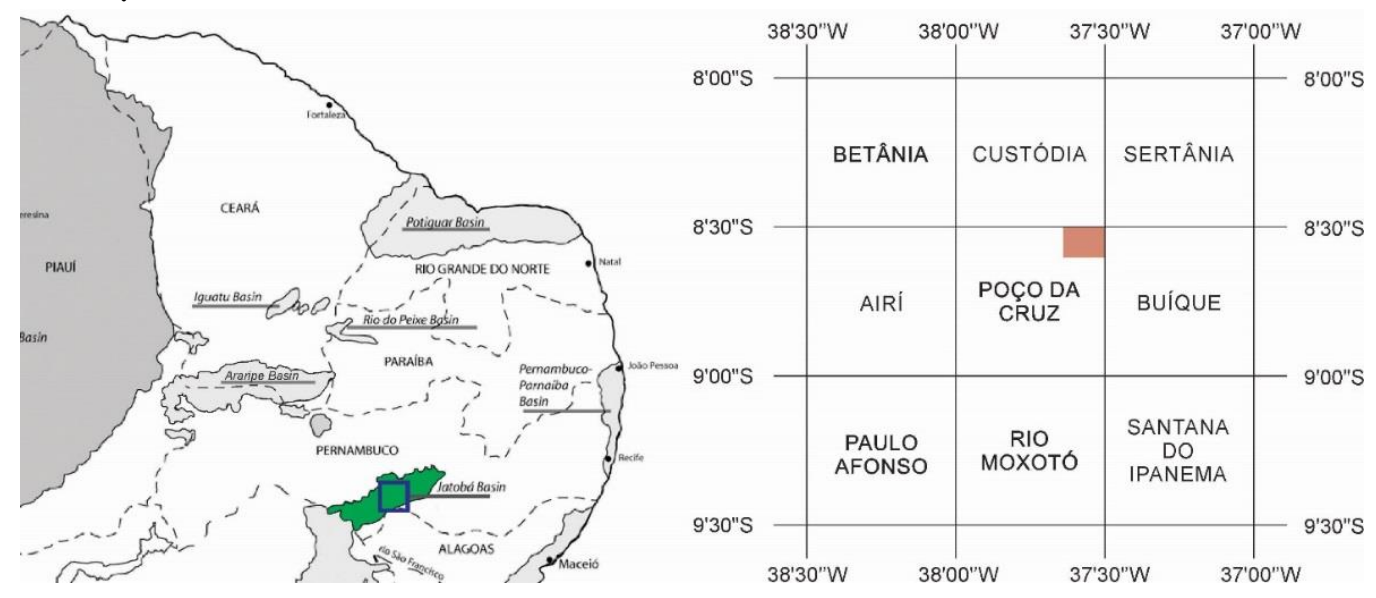

Figura 1. Localização da Bacia de Jatobá no nordeste brasileiro destacando-se em azul a Folha Poço da Cruz SC.24-X-A-VI e em vermelho a área mapeada (Modificado de Pires \& Guerra-Sommer, 2010).

\section{MATERIAIS E MÉTODOS}

Este trabalho foi desenvolvido em quatro etapas: a primeira fase consistiu na integração de dados geoespaciais, dentre os quais o mapeamento hidrogeológico realizado por Rocha \& Leite (1999), dados de fisiografia SRTM (Miranda, 2005), dados geofísicos de gamaespectrometria e magnetometria, fotografias aéreas e a Folha Poço da Cruz (SUDENE 1969) para compor um mapa previsional de domínios litológicos com as principais feições estruturais.

Foram realizadas duas etapas de campo para o reconhecimento da área, coleta de amostras e identificação das principais litologias e estruturas existentes. A descrição geológica ocorreu em 105 pontos ao longo da área e nos locais mais representativos foram coletadas nove amostras de rocha para confecção de seções delgadas para posterior análise por microscopia de luz transmitida. Também foram obtidas cinco amostras na região mapeada para tratamento e estudo micropaleontológico.

A caracterização fóssil ocorreu através de processamento em britador de mandíbula onde as amostras foram reduzidas a frações menores. Em seguida $60 \mathrm{~g}$ de cada amostra de rocha foram pesados e colocados em um béquer. Foram adicionados cerca de $100 \mathrm{ml}$ de peróxido de hidrogênio $\left(\mathrm{H}_{2} \mathrm{O}_{2}\right)$ na amostra, deixando-a reagir por 6 horas para ataque da matéria orgânica. Transcorrido o tempo, iniciou-se a etapa de lavagem em peneira de malha 500 a $45 \mu \mathrm{m}(500 \mu \mathrm{m}-250 \mu \mathrm{m}-180 \mu \mathrm{m}-62$ $\mu \mathrm{m}-45 \mu \mathrm{m})$.

As amostras foram depositadas separadamente em recipientes e levadas para secar em estufa a $60{ }^{\circ} \mathrm{C}$ durante 24 horas. Depois de seca, cada fração foi depositada em sacos plásticos previamente identificados. As frações consideráveis para análise de ostracodes são as de $<180 \mu \mathrm{m}$ e $<250 \mu \mathrm{m}$. Estas foram levadas para análise em microscópio estereoscópico para serem triadas.

Por fim, através da integração de todos os dados observados em campo e obtidos em estudos de laboratório com os existentes na literatura prévia foram confeccionadas quatro seções colunares dos afloramentos e elaborado o mapa geológico na escala de 1:50.000, conforme apresentado na Figura 2 


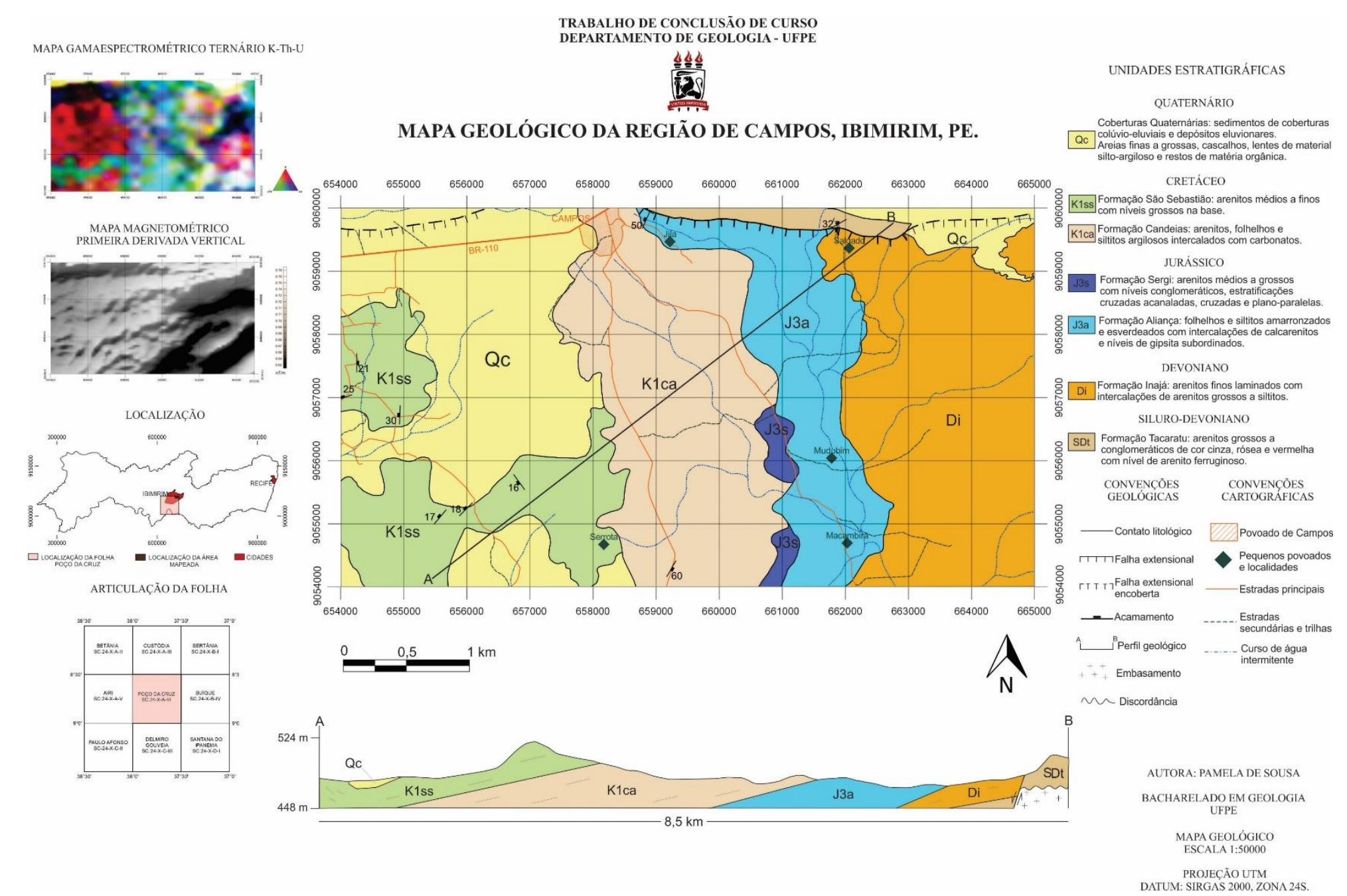

Figura 2. Mapa geológico da porção nordeste da Folha Poço da Cruz, na região de Campos, Bacia de Jatobá, NE brasileiro 


\section{CONTEXTO GEOLÓGICO REGIONAL}

A Bacia de Jatobá distribui a maioria dos seus $5000 \mathrm{~km}^{2}$ no estado de Pernambuco, na microrregião do Sertão do Moxotó, mas também ocupa uma pequena parte do estado da Bahia, na mesorregião do Vale SãoFranciscano da Bahia, e do estado de Alagoas, na mesorregião do Sertão Alagoano (Lima et al., 2011). Com trend NE-SW, seu registro sedimentar alcança a profundidade de 3000 m. A Falha de São Francisco e a Falha de Ibimirim limitam a bacia estruturalmente e controlam seu arcabouço estrutural e seu depocentro (Magnavita \& Cupertino, 1987, Costa et al., 2003, Rocha \& Amaral, 2007, Costa et al., 2007, Rocha, 2011). Compõe o Sistema Rifte Abortado Recôncavo-Tucano-Jatobá e marca a inflexão de N-S para $\mathrm{N} 70^{\circ} \mathrm{E}$ desse Sistema. Arquiteturalmente a bacia é caracterizada como um hemigráben constituído predominantemente por blocos rotacionados e progressivamente mais baixos em direção a NW (Rocha 2011), interpretados como uma tectônica transtrativa responsável pela geração e evolução da Bacia (Peraro 1995).

Segundo Costa et al. (2007), falhas normais planares de direção $\mathrm{N} 70^{\circ} \mathrm{E}$, sintéticas em relação à falha de borda, acomodam o mergulho das camadas a partir da margem flexural em direção ao depocentro. As principais feições estruturais da bacia são a supracitada Falha de Ibimirim (Falha de borda), o Gráben de Ibimirim (depocentro principal da bacia), o Horst do Icó, e as falhas de Mata Verde e Moxotó (Aragão \& Peraro, 1994, Peraro, 1995, LimaFilho et al., 2009, Rocha, 2011). Além destas temos também a já citada Falha do Rio São Francisco, limitando a bacia a oeste, e como estruturas de menor importância o Horst do Serrotinho, o Horst da Serra do Manari, a Falha de Fazenda Nova, a Falha de Manari e a Falha de Angico (Magnavita \& Cupertino, 1987, Santos et al., 1990, Peraro, 1995, Costa et al,. 2003, Costa et al., 2007, Rocha \& Amaral 2007, Rocha 2011). Na Figura 3 podemos ver a representação esquemática das suas principais feições estruturais

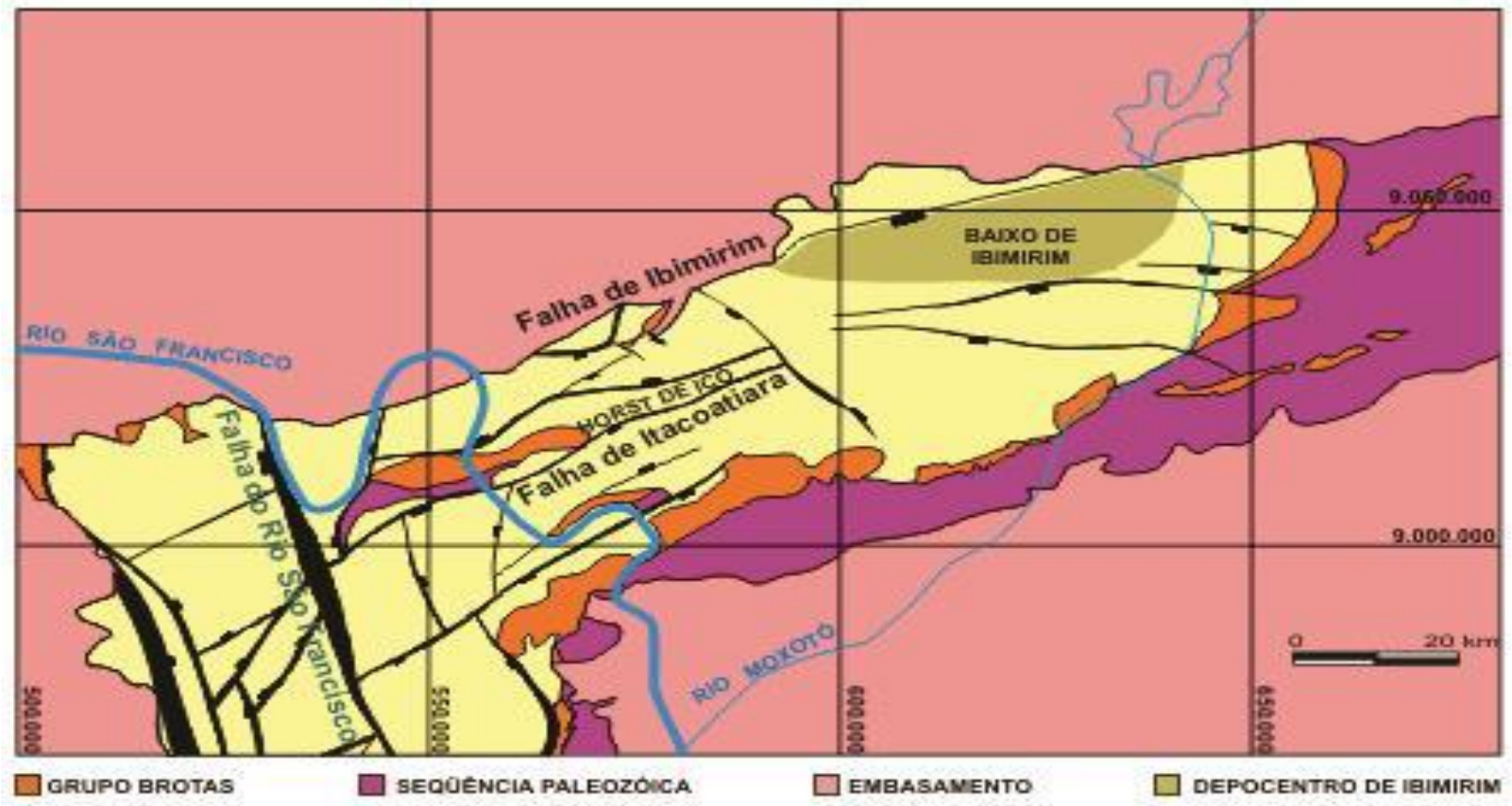

Figura 3. Limites do Arcabouço Estrutural da Bacia de Jatobá, destacando-se suas principais feições estruturais (Costa et al., 2003). 
A litoestratigrafia foi subdividida nas tectonosequências Beta, Pré-Rifte, Rifte, Pós-Rifte e Zeta por Rocha \& Amaral (2007), no entanto, este trabalho apresenta uma divisão litoestratigráfica baseada na proposta de Fambrini et al. (2010, 2011), em base ao modelo de Prosser (1993) para a Bacia do Araripe e a modificação de Kuchle (2010) ao modelo citado e aplicação por Guzmán et al. (2015). Subdividindo a Bacia de Jatobá em Sequência Sinéclise, compreendidas as Formações Tacaratu e Inajá; Sequência de Início de Rifte, reunindo as Formações
Aliança e Sergi; Sequência de Clímax de Rifte, com as Formação Candeias, Grupo Ilhas, Formação São Sebastião e Formação Salvador conforme descrito por Horn \& de Morais (2016); e Sequência Pós-Rifte, incluindo a Formação Marizal, Grupo Santana e Formação Exu. A coluna estratigráfica da Bacia de Jatobá que representa a proposta de Fambrini et al. $(2010,2011)$ supracitada pode ser observada na Figura 4, de acordo com Guzmán et al. (2015), adaptado de Horn \& de Morais (2016) e Queiroz et al. (2017).

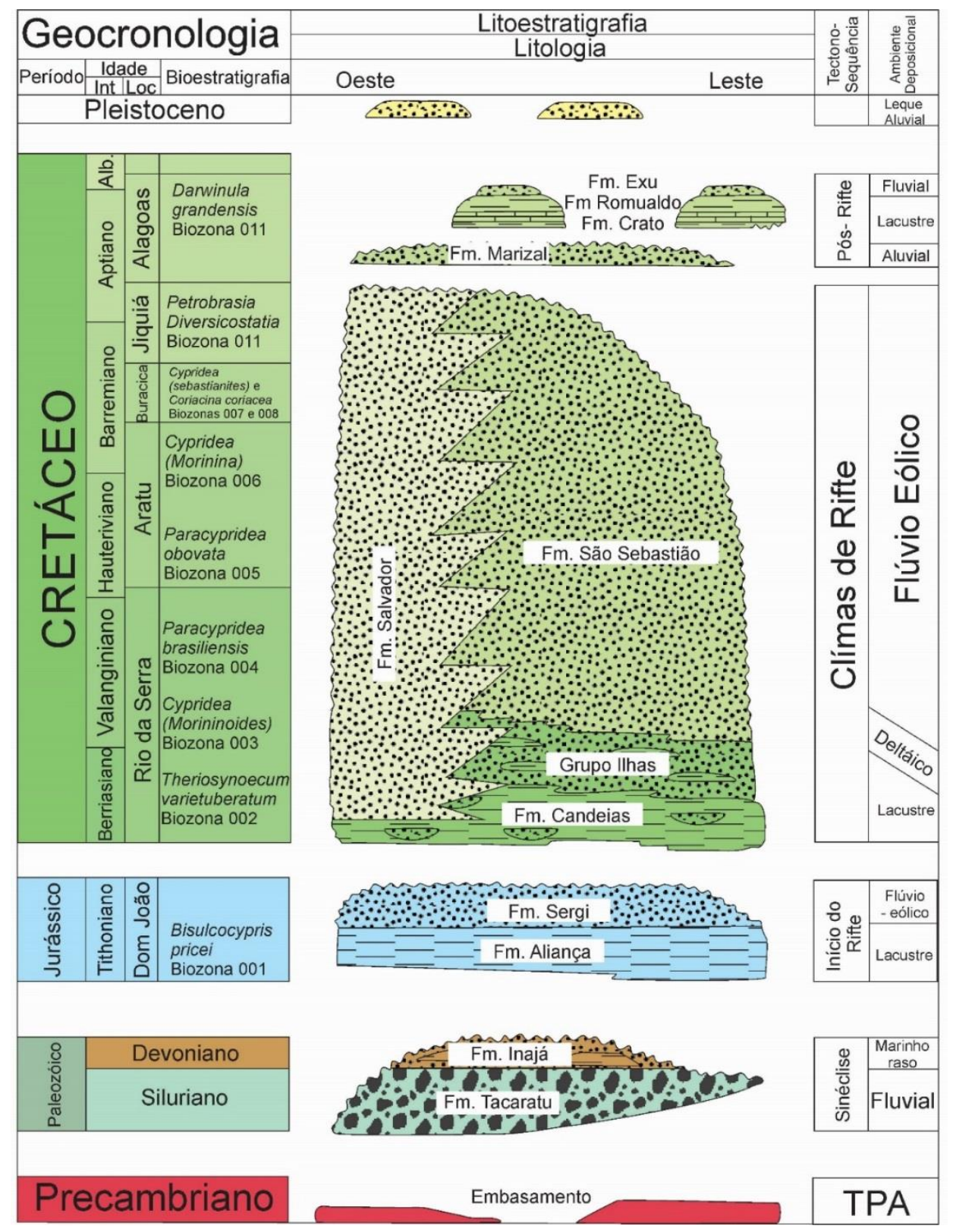

Figura 4. Carta estratigráfica da Bacia de Jatobá (Adaptada de Horn \& de Morais, 2016 e Queiroz et al., 2017) 
A Formação Tacaratu é representada por arenitos cinza esbranquiçados a róseo avermelhados de tamanho de grão correspondente a areia grossa, chegando a apresentar níveis conglomeráticos. Morfologicamente, compõe um relevo bastante acidentado, com encostas abruptas e terrenos íngremes. Em algumas áreas o intemperismo esculpe formas de aspecto ruiniforme, característica marcante desta formação que dá a identidade das paisagens do Parque Nacional do Vale do Catimbau (Rocha, 2011). Depositada provavelmente no Siluro-Devoniano, a formação possui características típicas de ambiente fluvial entrelaçado (braided), associado, inicialmente, a leques aluviais, evoluindo para uma fácies mediana a distal, com características de planície de inundação e posterior retrabalhamento eólico (Rocha \& Leite, 1999, Carvalho et al., 2018). Esta formação pode ser correlacionada ao Grupo Serra Grande, na Bacia do Parnaíba (Caputo \& Crowell, 1985, Ghignone, 1972, Assine, 1992, 2007, Caixeta et al., 1994) e à Formação Cariri na Bacia do Araripe (Braun 1966).

A Formação Inajá constitui-se por arenitos finos, siltitos e folhelhos com colorações que variam do cinza ao creme e do róseo ao vermelho ferruginoso. Apresentam também intercalações com níveis de arenitos grossos a conglomeráticos (Dantas \& LimaFilho, 2007). O contato inferior da Formação Inajá com a Formação Tacaratu é gradativo e concordante (Rocha \& Amaral, 2007). Morfologicamente a interação dos pacotes de arenito contendo estratificação cruzada e sets pouco espessos com lâminas e estratos de granulometria mais fina produzem um aspecto lajotado em alguns afloramentos representativos dessa formação (Barreto 1968). Segundo Pereira et al., (2012), a Formação Inajá documenta o primeiro ciclo deposicional em condições ortoplataformais no Devoniano da bacia, com a predominância de ambiente deposicional marinho de plataforma rasa de águas moderadamente quentes de salinidade normal, baseado em sua fauna fóssil de bivalves e braquiopódes, e discordante no seu contato superior com a
Formação Aliança (Rocha \& Amaral, 2007). A Formação Inajá correlaciona-se à Formação Pimenteiras e seu topo correlaciona-se ainda à Formação Cabeças, ambas na Bacia do Parnaíba (Barreto, 1968).

A Formação Aliança aparece em afloramentos aplainados com ligeiras ondulações devido a sua natureza dominantemente pelítica. É composta, basicamente, por folhelhos e siltitos amarronzados e esverdeados, com intercalações de arenitos finos, localmente grossos, além de calcarenitos e calcissiltitos esbranquiçados a marrom claro, fossilíferos, e mais raramente, níveis de evaporitos. Nos níveis carbonáticos, dominam os calcarenitos finos fossilíferos, geralmente de cores claras, contendo bioturbações, com forte diagênese ou localmente silicificados (Rocha \& Amaral, 2007). Ela é correlacionada à Formação Brejo Santo, Bacia do Araripe e à Formação Bananeiras, da Bacia SE/AL (Braun, 1966, Schaller, 1969, Ponte, 1994, Valença et al., 2003, Assine, 2007, Campos Neto et al., 2007, Costa et al., 2007, Fambrini et al., 2011, 2013a).

A formação Sergi é composta de arenitos com tamanho de grão que varia de areia grossa a fina, por vezes conglomeráticos, com algumas intercalações de siltitos de coloração creme com tons avermelhados, apresentando estratificações cruzadas acanaladas. Apresenta conteúdo fossilífero importante, materiais vegetais fossilizados representados por madeira silicificada. Possui origem associada a um sistema fluvial entrelaçado (braided), com posterior retrabalhamento eólico sob condições de clima árido a desértico (Rocha 2001). A Formação Sergi correlaciona-se ás Formações Missão Velha e Serraria nas Bacias do Araripe e SE/AL, respectivamente (Arai, 2006, Braun, 1966, Schaller, 1969, Ponte, 1994, Valença et al., 2003, Assine, 2007, Campos Neto et al., 2007, Costa et al., 2007, Fambrini et al., 2011, 2013a; Kuchle et al., 2011).

A Formação Candeias é dominantemente pelítica e composta por folhelhos e siltitos argilosos de coloração marrom e esverdeados, contendo 
intercalações de arenitos finos calcíferos e margas, e arenitos de granulometria fina a média que é o que difere esta formação da qual está sobreposta, a Formação Aliança, assim como as características de seu conteúdo fossilífero como os fósseis de peixes, ostracodes e plantas carbonizadas ou silicificadas (Caixeta et al., 1994, Costa et al., 2003, Costa et al., 2007, Rocha \& Amaral, 2007, Rocha, 2011, Sousa et al., 2013). Os ostracodes mais importantes são os da zona Theriosynoecum varietuberatum GrekofflKrommelbein e Paracypridea brasiliensis Krommelbein de acordo com Costa et al. (2007), que posicionaram a Formação Candeias no Andar Rio da Serra (Eo/Neoberriasiano), com o registro de um ambiente lacustre mais profundo, evidenciando que além das variações climáticas mais úmidas também ocorreu um progressivo aumento na taxa de subsidência da bacia (Campos Neto et al., 2007). Ela representa a segunda fase lacustre na Bacia de Jatobá, durante o Clímax de Rifte. É correlacionada à Formação Barra de Itiúba, da Bacia SE/AL (Menezes Filho et al., 1988).

A Formação Salvador, descrita na Bacia de Jatobá por Horn \& de Morais (2016), é caracterizada por pacotes métricos de conglomerados e finas camadas de arenito indicando uma deposição sob sistema aluvial, como também folhelhos avermelhados e argilitos contendo calcário oolítico caracterizando fácies de ambiente lacustre.

A Formação São Sebastião apresenta feições de serras arredondadas, escarpadas e morrotes ondulados ao longo de uma faixa NE-SW, na região do povoado de Campos, Ibimirim (Rocha \& Amaral, 2007). Segundo Rocha (2011), Queiroz et al. (2017) e Fambrini et al. (2013b, 2019), ela é constituída na base, por arenitos avermelhados, variando de grossos a finos, de seleção regular, por vezes oxidados. Para o topo a sequência está caracterizada por arenitos róseos a creme, de grãos finos a muito finos, bem selecionados, bimodais, dispostos em estratos bandados de aspecto rítmico. Possui estratificações cruzadas acanaladas de grande porte e idade neovalanginiana-eohauteriviana, sendo associada a um sistema fluvial entrelaçado (Fambrini et al., 2006, 2007, 2013b) com posterior retrabalhamento eólico, onde a porção basal caracteriza um sistema fluvial de alta energia (Fambrini et al., 2007) e o restante registra um ambiente desértico tipicamente eólico (Rocha \& Amaral, 2007, Fambrini et al., 2006, 2013b, 2019). Ponte \& Appi (1990) e Ponte et al. (1997) a correlatam às formações Penedo, Coqueiro Seco e Morro do Chaves, na Bacia SergipeAlagoas.

\section{LEVANTAMENTO E RESULTADOS}

$\mathrm{Na}$ região mapeada afloram seis litologias principais além das coberturas elúvio-coluvionares, que compõem sua maior parte. São elas a Formação Tacaratu, Formação Inajá, Formação Aliança, Formação Sergi, Formação Candeias e Formação São Sebastião.

\section{Formação Tacaratu}

Identificada na parte norte da área, esta unidade litológica apresenta arenitos grossos e médios por vezes conglomeráticos de coloração creme alaranjada e acinzentada. Os afloramentos são rasteiros e friáveis remanescentes de uma acentuada ação do intemperismo, aplainando o relevo, conforme a Figura 5. 


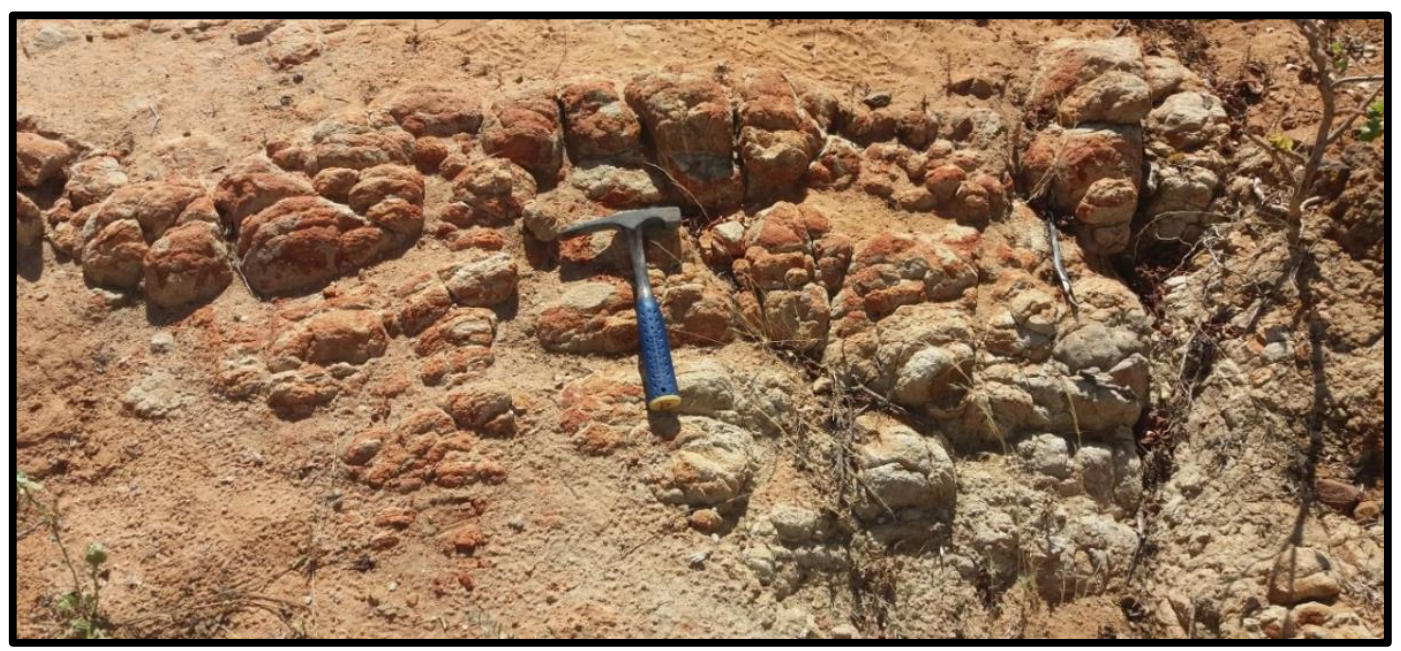

Figura 5. Arenitos grossos e médios da Formação Tacaratu, na localidade Jila (coordenadas: 658833; 9059991).

Em níveis topográficos mais elevados, a unidade apresenta-se como um arenito creme esbranquiçado, com tamanho de grãos correspondente a areia média e sequenciados níveis conglomeráticos de pouca espessura. Os arenitos apresentam estratificações cruzadas tabulares de médio porte e abundantes bandas de deformação na direção NE e a NW (Fig. 6A), sendo esta última menos recorrente. $\mathrm{O}$ afloramento apresenta feições erosivas como sulcos e ravinas, decorrentes da erosão ocasionada por leitos de rios intermitentes que ocorrem no local (Fig. 6B).

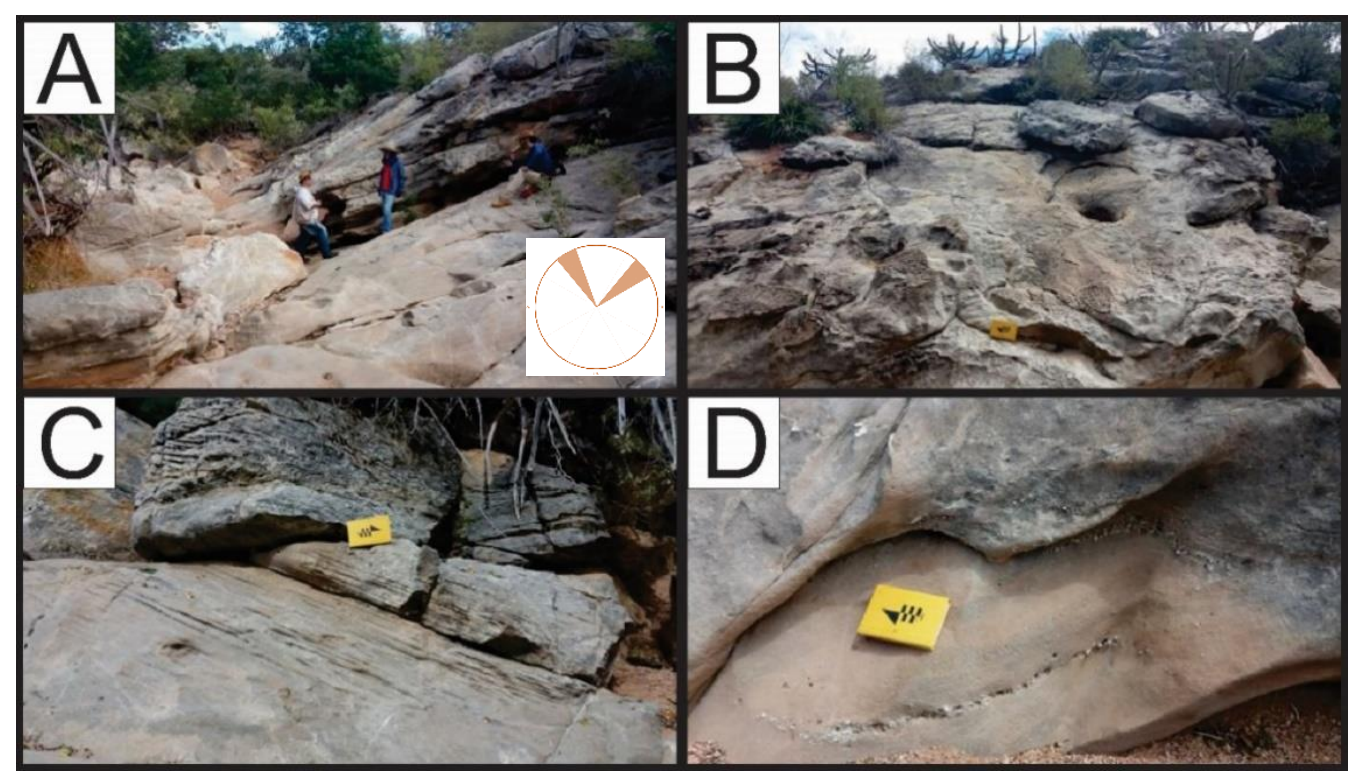

Figura 6. Fotos de afloramentos próximos à localidade Puiú (coordenadas: 661888; 9059747).

A) Visão geral do afloramento da Formação Tacaratu em níveis topográficos mais elevados, estereograma apresenta direções gerais das bandas de deformação. B) Feições erosivas fluviais resultantes de intemperismo físico. C) Estratos plano paralelos no pacote inferior e blocos rolados oriundos da mesma unidade litológica. D) Níveis conglomeráticos de pouca espessura intercalados com arenitos médios. 
Há também na localidade um contato entre o topo da Formação Tacaratu e a base da Formação Inajá. Embora coberta por sedimentos eluviais, a variação litológica é nítida e permite a medição de paleocorrentes sub-horizontais com direção de $300 \mathrm{Az}$ nos arenitos da formação Tacaratu (Fig. 7). Integrando características litológicas, estruturais e localização geográfica, é concebível que a unidade em questão se trate da Formação Tacaratu, registro sedimentar de idade siluro-devoniana da bacia.

\section{Formação Inajá}

A Formação Inajá foi identificada na porção nordeste e sudeste da área de estudo, com afloramentos formados por arenitos médios a finos com tons que variam do creme acinzentado a um vermelho ferruginoso à medida que se aproximam do topo da camada, conforme a Figura 8. Percebem-se níveis com maior tamanho de grão concentrado nas porções basais esbranquiçadas e menores tamanhos de grãos no topo avermelhadas. As porções mais basais são também as mais friáveis. Estruturalmente pode-se perceber um acamamento plano paralelo, com mergulhos de $20^{\circ}$ a $22^{\circ}$ para SSW, decorrentes da proximidade com a Falha de Ibimirim

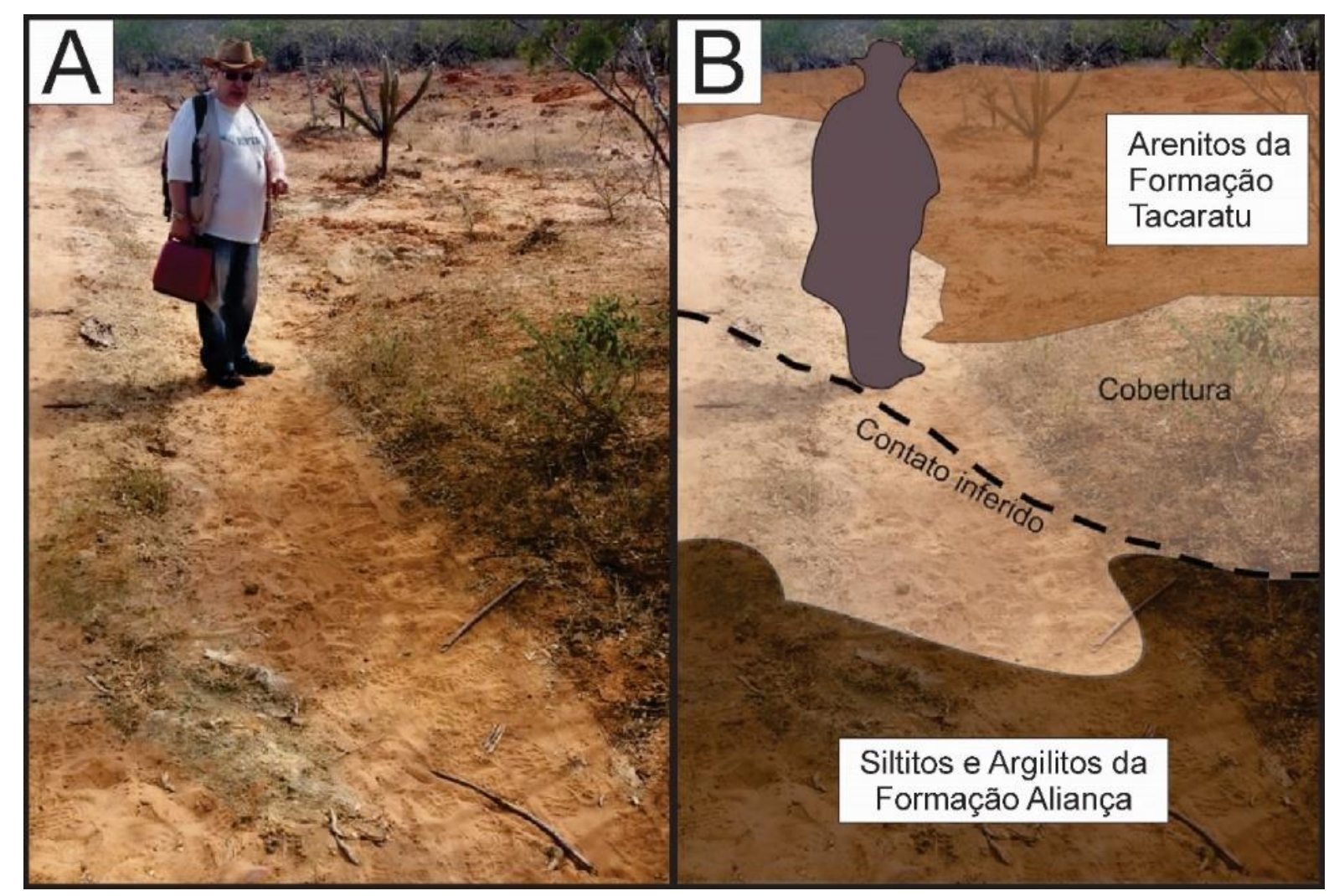

Figura 7. Contato inferido entre o topo da Formação Tacaratu, na qual se observam paleocorrentes sub-horizontais com direção de $300 \mathrm{Az}$, e base da Formação Inajá. Localidade Jila (coordenadas: 658833; 9059991). 


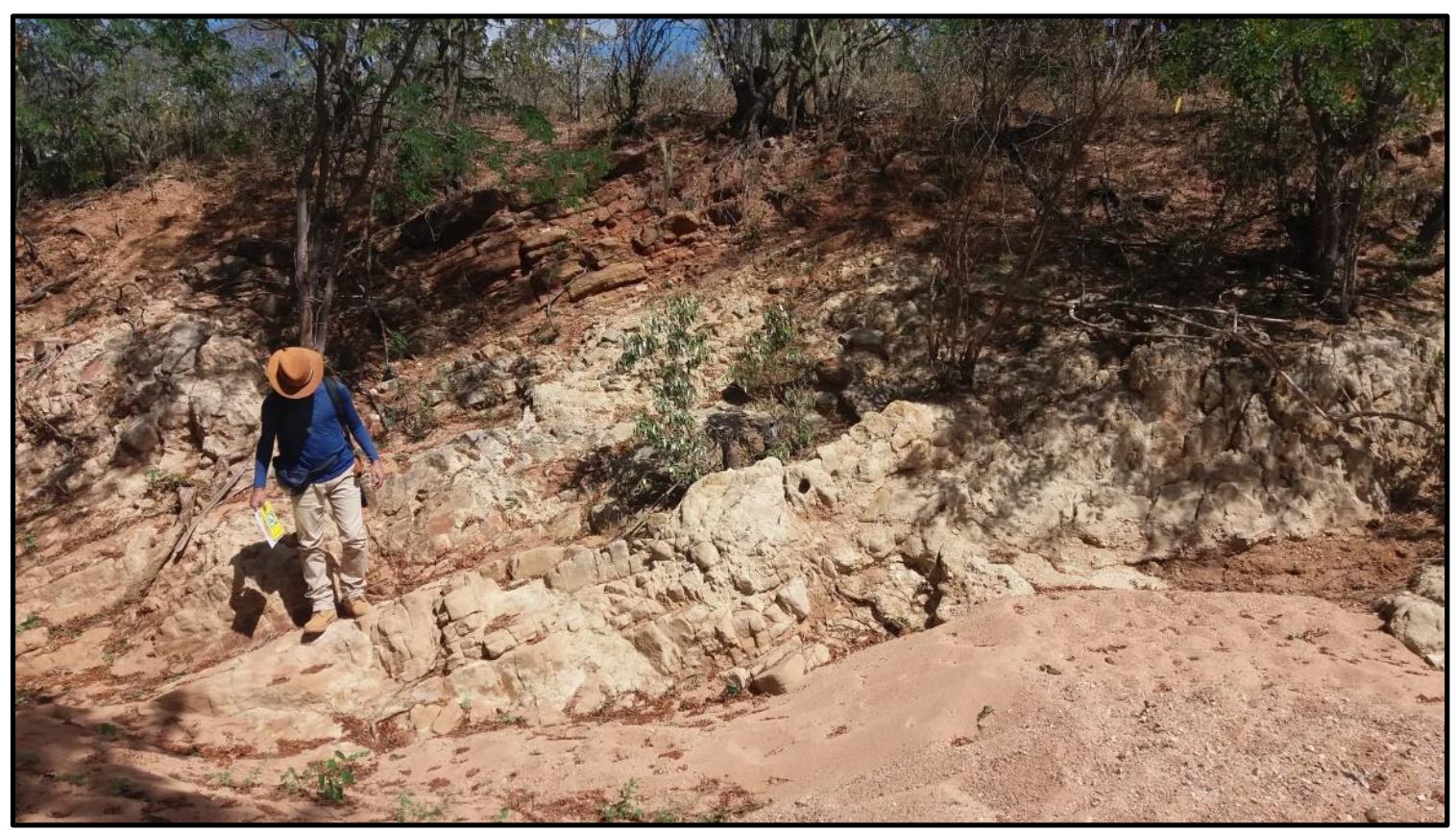

Figura 8. Aspecto geral dos arenitos médios a finos da Formação Inajá existente na porção norte da área mapeada (coordenadas: 661876; 9059649).

A seção colunar exibida na Figura 9 apresenta, de forma mais precisa, as variações faciológicas presentes no afloramento. Na base, arenito médio a grosso com granodecrescência ascendente dentro dos sets. Em seus níveis mais grossos predomina o tamanho de grão correspondente ao cascalho muito fino, com sedimentos bem arredondados e de baixa esfericidade, caracterizando a litofácies Stc. O acamamento encontra-se bem exposto e apresenta atitudes de paleocorrentes com valores de 190/22 e 176/20. Na camada intermediária o tamanho de grão decresce à medida que se aproxima do topo e as estratificações ficam menos proeminentes, definindo a litofácies St. Culmina-se, enfim, na camada superior que é identificada pela mudança expressiva da coloração, de creme para um alaranjado intenso, ainda na litofácies St. Nesse último pacote os sets se tornam menos espessos, o que reflete uma gradual mudança dos fatores controladores da deposição, afetando o suprimento sedimentar.

Os afloramentos da Formação Inajá que estão localizados na porção sudeste da área mapeada surgem em voçorocas intemperizadas, onde é visível a alteração da rocha sã para o solo residual, conforme a Figura 10. Nesta localidade a Formação Inajá se apresenta como arenitos finos a médios, com alguns níveis mais grossos a conglomeráticos, de coloração cinza a creme amarelados, róseos e vermelhos ferruginosos subpostos à rocha alterada, que ocorre sob a forma de rocha em degradação e o saprólito. $\mathrm{O}$ solo residual pode ser dividido em solo jovem e maduro, ambos na forma de elúvio, ou seja, o material derivado dos processos de alteração e decomposição in situ da rocha e que não foi transportado do seu local original. 


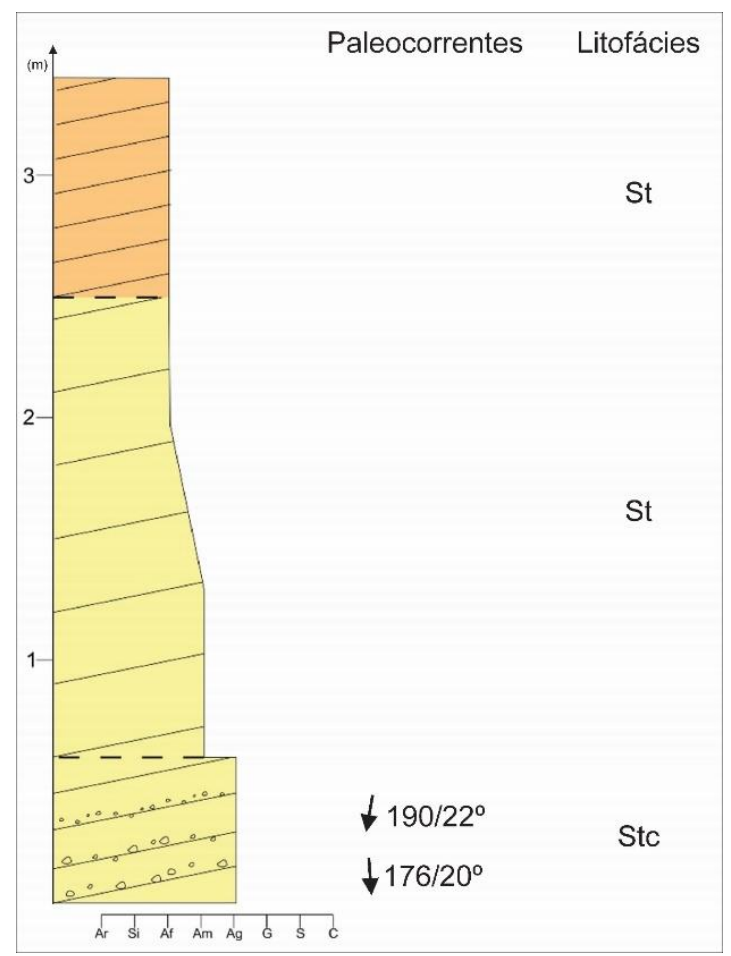

Figura 9. Seção colunar da Formação Inajá mostrando na base um arenito médio a grosso com pronunciada granodecrescência ascendente dentro dos sets e níveis conglomeráticos de cascalho muito fino bem arredondados e de baixa esfericidade, pertencente a litofácies Stc. Na camada intermediária há uma diminuição de tamanho de grão na medida em que se aproxima do topo exibindo estratificações menos proeminentes, caracterizando a litofácies St. Na camada superior vemos uma mudança expressiva da coloração, do creme para o alaranjado intenso e ocorrência de sets menos espessos, decorrente de menor suprimento sedimentar, novamente de litofácies St.

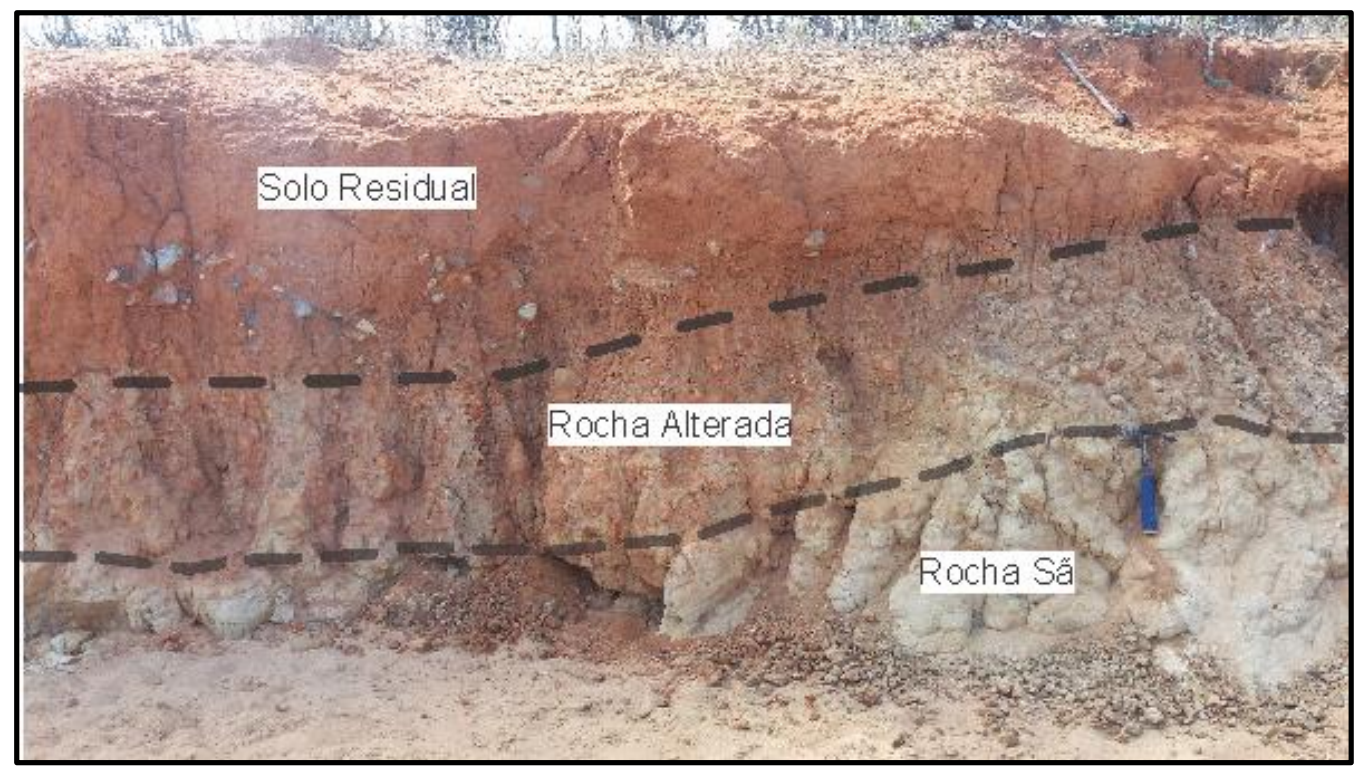

Figura 10. Transição dos diferentes graus de intemperismo, desde a rocha sã até o solo residual, dos arenitos finos a médios, com alguns níveis mais grossos a conglomeráticos, de coloração cinza a creme amarelados, róseos e vermelhos ferruginosos da Formação Inajá (coordenadas: 663225; 9054810). 


\section{Formação Aliança}

As ocorrências da Formação Aliança estão distribuídas seguindo um trend $\mathrm{N}-\mathrm{S}$ ao longo da área de estudo, com a maioria dos afloramentos localizados na porção centro leste. Eles configuram áreas predominantemente planas e suavemente onduladas, cujo relevo aplainado é justificado pela fração granulométrica predominantemente pelítica das rochas.

Esta formação apresenta espessos pacotes argilosos a síltico-argilosos, de cor vermelho-castanho, por vezes arroxeados, contendo finas camadas de mesmo tamanho de grão e cor verde a cinza esverdeado. Essas camadas estão constantemente intercaladas com níveis de rochas carbonáticas, como calcários, calcarenitos e arenitos calcíferos, estes últimos em menor proporção. O contato entre essas duas litologias distintas se dá de forma abrupta e sub-horizontal.
Os pacotes síltico-argilosos se encontram desagregados e cobrem a maior extensão das áreas aflorantes. O tamanho de grão predominante não sofre modificações significativas em todo intervalo, apresentando-se bastante quebradiços e por vezes físseis, caracterizando folhelhos.

As maiores espessuras concentram-se em folhelhos tipicamente avermelhados com elevadas concentrações de ferro férrico $\left(\mathrm{Fe}^{3+}\right)$, variando em tons castanhos e roxos, os quais caracterizam red beds cuja gênese se desenvolveu sob um ambiente fortemente oxidante. Subordinadamente ocorrem níveis delgados esverdeados desses pelitos com concentrações de ferro ferroso $\left(\mathrm{Fe}^{2+}\right)$, desenvolvidas em ambiente redutor (Fig. 11). Esparsamente, foram observadas lâminas de gipsita $\left(\mathrm{CaSO}_{4}\right)$ associadas aos horizontes esverdeados.

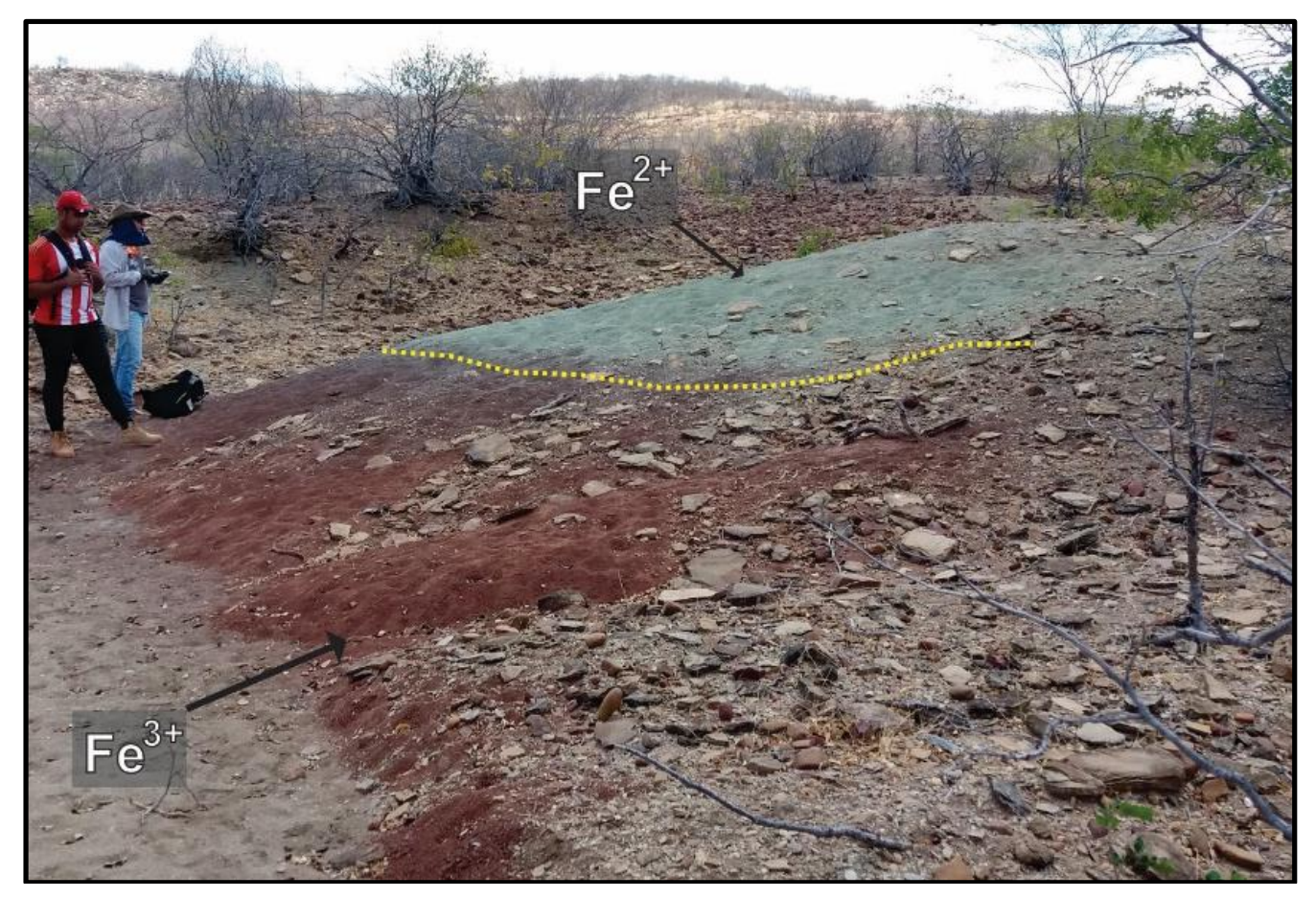

Figura 11. Diferença na coloração dos sedimentos síltico-argilosos da Formação Aliança em função do estado catiônico do ferro durante a dinâmica deposicional. Em ambiente predominantemente oxidantes $\left(\mathrm{Fe}^{3+}\right)$ os grãos apresentam coloração avermelhada, enquanto em ambientes redutores $\left(\mathrm{Fe}^{2+}\right)$ eles possuem cor verde a cinza esverdeada (coordenadas: 661605; 9054772). 


\section{GEOLOGIA DA ÁREA NORDESTE DA FOLHA POÇO DA CRUZ...}

Os níveis carbonáticos da Formação Aliança são representados por camadas decimétricas de calcários bioclásticos creme, bastante rígidos, com numeroso conteúdo macro e microfossilífero. Nesses níveis também são encontrados pellets de argila, formados por material removido das camadas pelíticas inferiores e redepositados durante os processos precipitantes do material carbonático. Ainda na Figura 11 é possível notar que acima desta unidade existiu um nível carbonático e que este se encontra desagregado, devido à existência de blocos rolados de calcários sobrepostos à camada pelítica verde. Tais afloramentos ocorrem mais expressivamente nas localidades de Macambira e Modubim.

$\mathrm{O}$ afloramento Macambira se localiza na região sul-sudeste da área. Tem como litologias o pelito oxidado vermelho (red bed) e, em suas porções mais basais, camadas delgadas de pelito reduzido verde associado a um calcário bioclástico bastante consolidado e fossilífero. Na Figura 12 pode-se perceber como essas litologias estão dispostas espacialmente no afloramento, enquanto na Figura 13 temos a seção colunar confeccionada a partir do empilhamento das camadas sedimentares vistas em campo. Nela podemos identificar a alternância entre os pacotes argilosos a síltico-argilosos vermelho-castanho a arroxeados correspondentes a litofácies $P o$, os sedimentos argilosos a síltico-argilosos verde a cinza esverdeado da litofácies $P r$, os calcários e calcarenitos bioclásticos $\mathrm{Cbcl}$ e não bioclásticos $\mathrm{Ca}$.

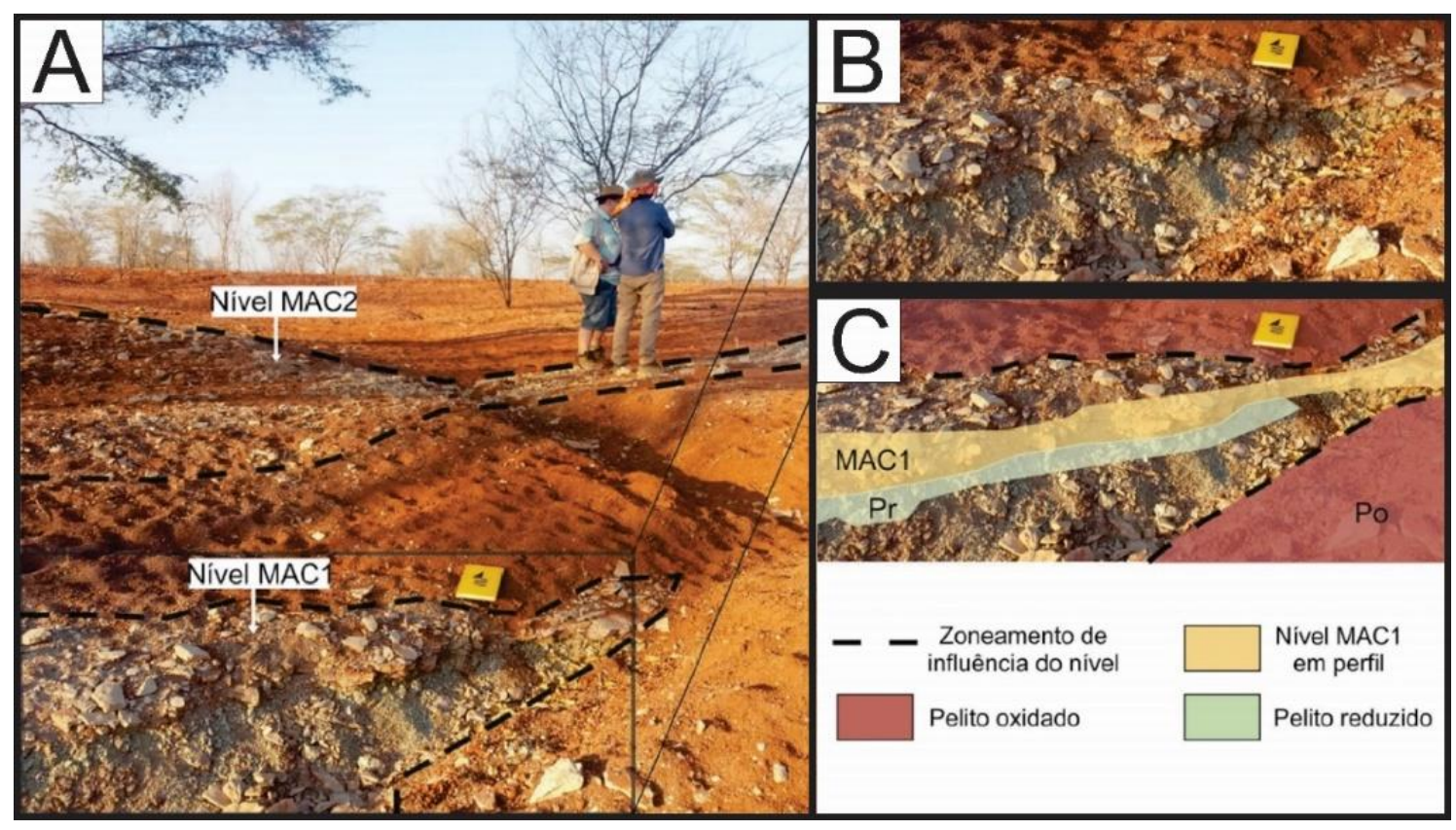

Figura 12. A) Disposição dos níveis carbonáticos Macambira 1 (MAC1) e Macambira 2 (MAC2) associados aos pelíticos oxidado e reduzido ao longo do afloramento Macambira (coordenadas: 661237; 9055639). B) Detalhamento do nível carbonático Macambira 1 (MAC1). C) Interpretação do nível carbonático Macambira 1 (MAC1) demonstrando seus limites e as litologias circundantes correspondente aos pelitos oxidados e reduzidos. 


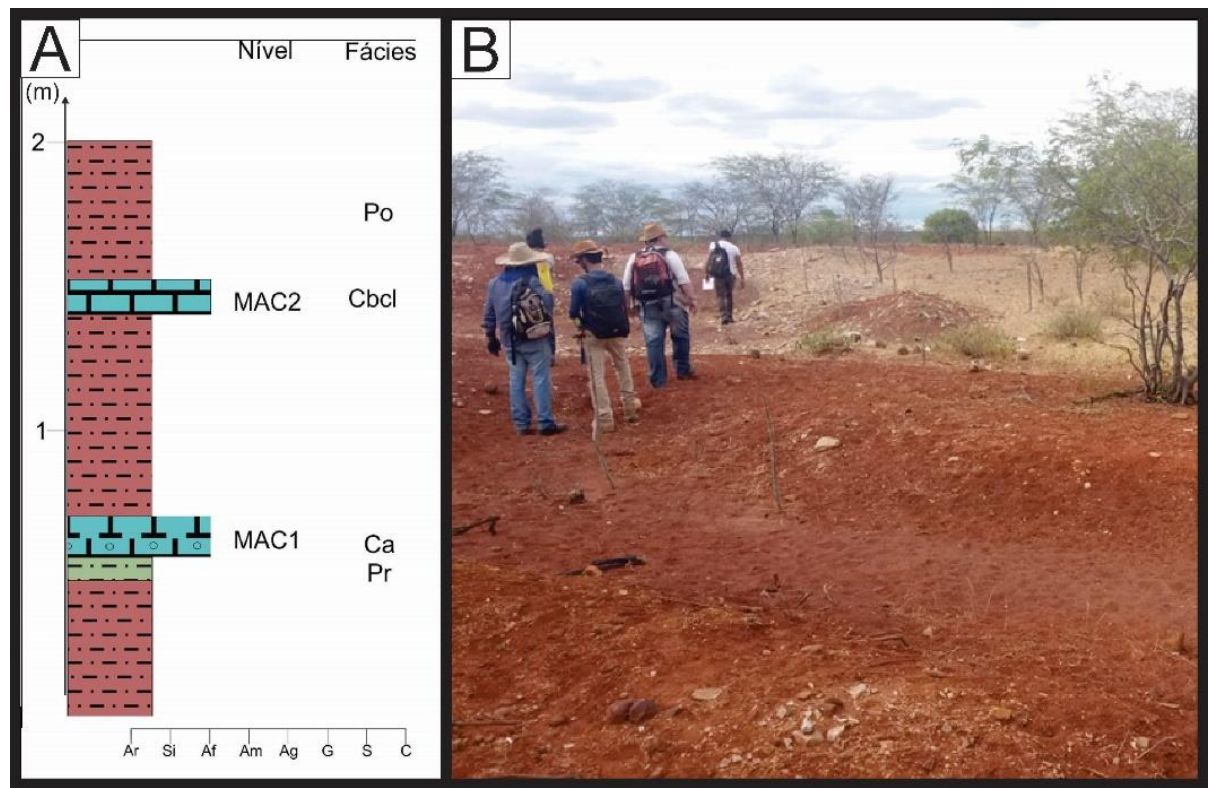

Figura 13. A) Seção Colunar do afloramento Macambira com pelitos argilosos a síltico-argilosos vermelho-castanho a arroxeados da litofácies $P o$, pelitos argilosos a síltico-argilosos verde a cinza esverdeado da litofácies $\mathrm{Pr}$, calcários e calcarenitos bioclásticos $\mathrm{Cbcl}$ e calcários e calcarenitos não bioclásticos da litofácies $C a$. B) Visão geral do afloramento.

No afloramento Macambira ocorrem dois níveis carbonáticos. $\mathrm{O}$ primeiro (MAC1), com espessura de $14 \mathrm{~cm}$, distinguese por conter em sua posição mais basal uma camada de calcarenito com tamanhos de grão correspondentes à areia fina dispostos entre porções mais concentradas de bioclastos. Essa camada faz contato gradual com o calcário bioclástico, onde os grãos são quase que em sua totalidade compostos de ostracodes e conchostráceos.

O segundo nível (MAC2), contém 12 $\mathrm{cm}$ de calcário bioclástico. É possível observar os bioclastos a olho nu ou com auxílio de lupa de mão. Nesse nível, altamente fossilífero, são encontrados icnofósseis, que configuram intensa atividade biológica enquanto o material depositado ainda se encontrava inconsolidado, fragmentos de dentes e partes esqueletais de peixe da espécie Lepidotes (Fig. 14A), além dos ostracodes e conchostráceos. Estruturas comuns são amígdalas preenchidas por material silte-argiloso (Fig. 14B).

$\mathrm{O}$ afloramento Modubim se localiza à norte do Macambira e, apesar de sua similaridade faciológica, ele apresenta suas particularidades. Dentre elas a presença de fragmentos de lâminas de gipsita e o fato dos pacotes pelíticos e níveis carbonáticos serem mais espessos que os observados em Macambira. A diferenciação ao empilhamento visto no afloramento anterior se dá pela ocorrência de uma delgada camada de gipsita $\left(\mathrm{CaSO}_{4}\right)$ de aproximadamente 2 $\mathrm{cm}$, vista em detalhe na Figura 15.

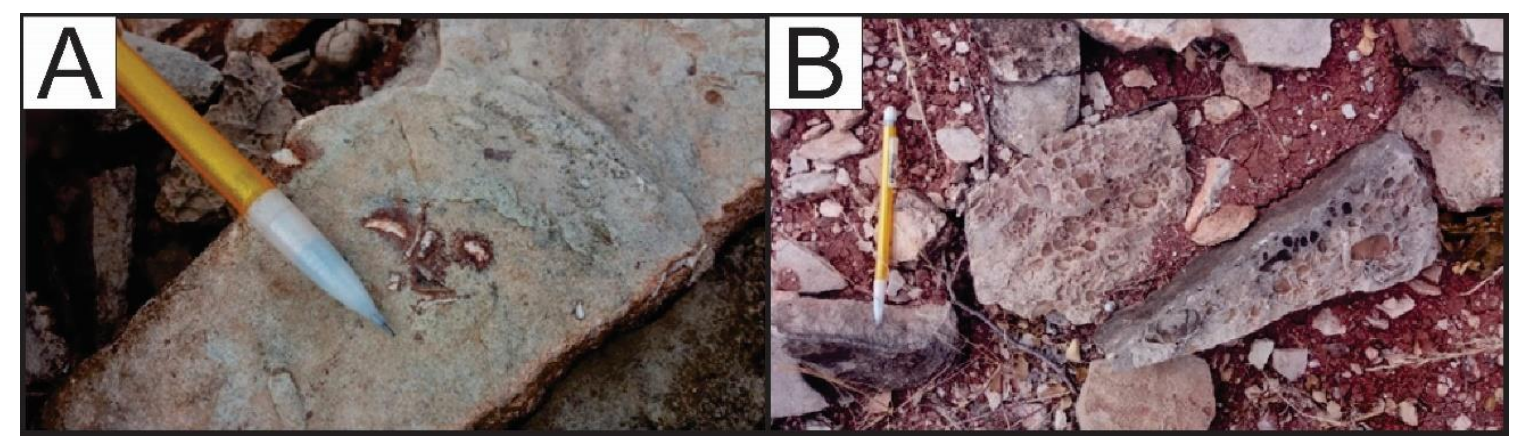

Figura 14. Detalhes do nível carbonático MAC2. A) Fragmentos ósseos fósseis B) Estruturas vesiculares dispersas no interior do nível. 


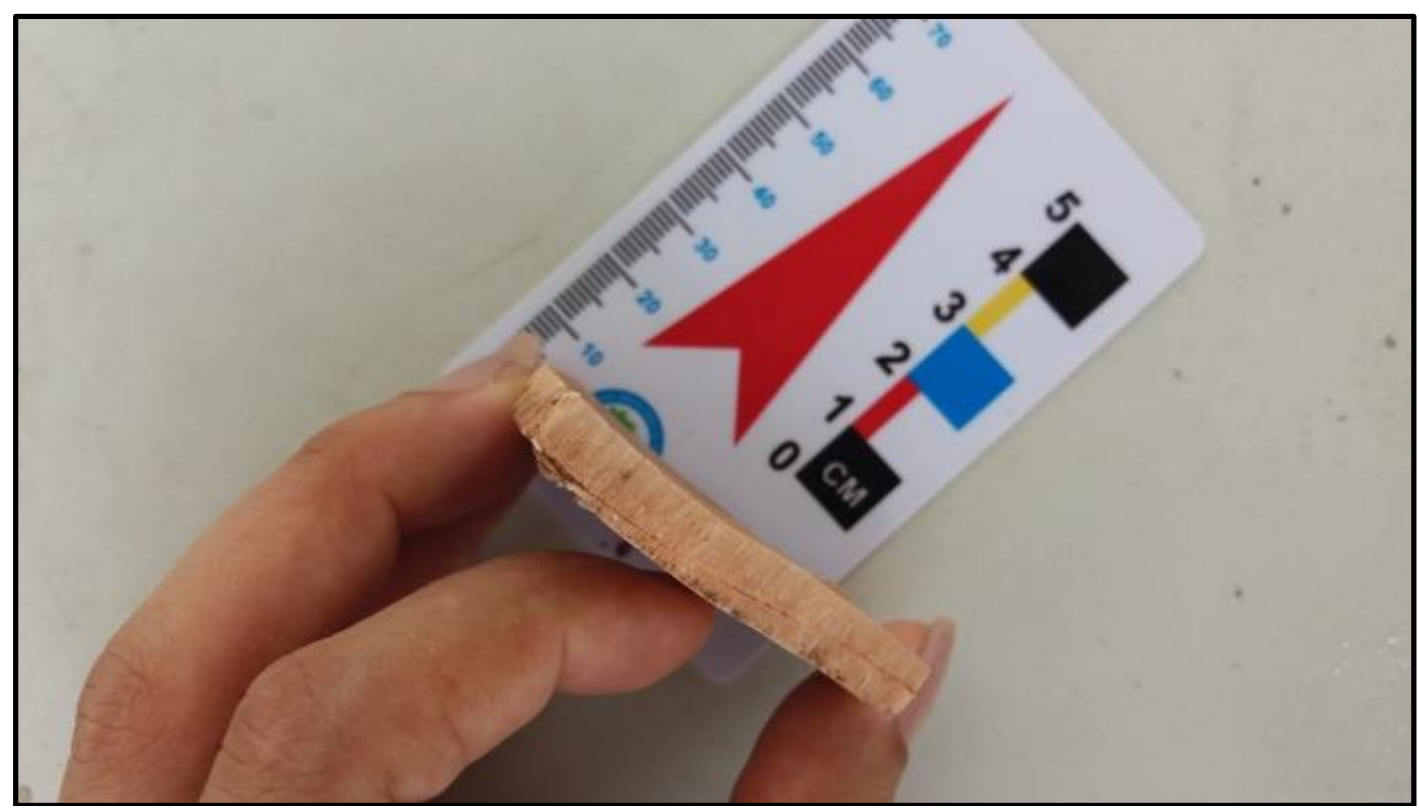

Figura 15. Detalhe da amostra de uma das lâminas de gipsita da Formação Aliança encontrada no afloramento Modubim.

A gipsita apresenta-se associada à porção reduzida do material pelítico e a camada em que ela ocorre se encontra superficialmente deteriorada, deixando exposto apenas pequenas placas irregulares de tamanhos variados, sendo as maiores com arestas de 5 a $7 \mathrm{~cm}$.

Nesse ambiente, o pelito avermelhado oxidado adquire tons arroxeados nas proximidades do pelito esverdeado reduzido. A coloração decorre de uma zona de transição, onde os materiais pelíticos se misturam e os estados catiônicos do ferro $\mathrm{Fe}^{2+}$ e $\mathrm{Fe}^{3+}$ existem em proporções equiparadas. A Figura 16 mostra seu aspecto geral e seção colunar, indicando como se relacionam os níveis carbonáticos no afloramento Modubim (MOD1, MOD2, MOD3, MOD4 e MOD5) e os pacotes pelíticos e de acordo com o padrão de litofácies observado. 


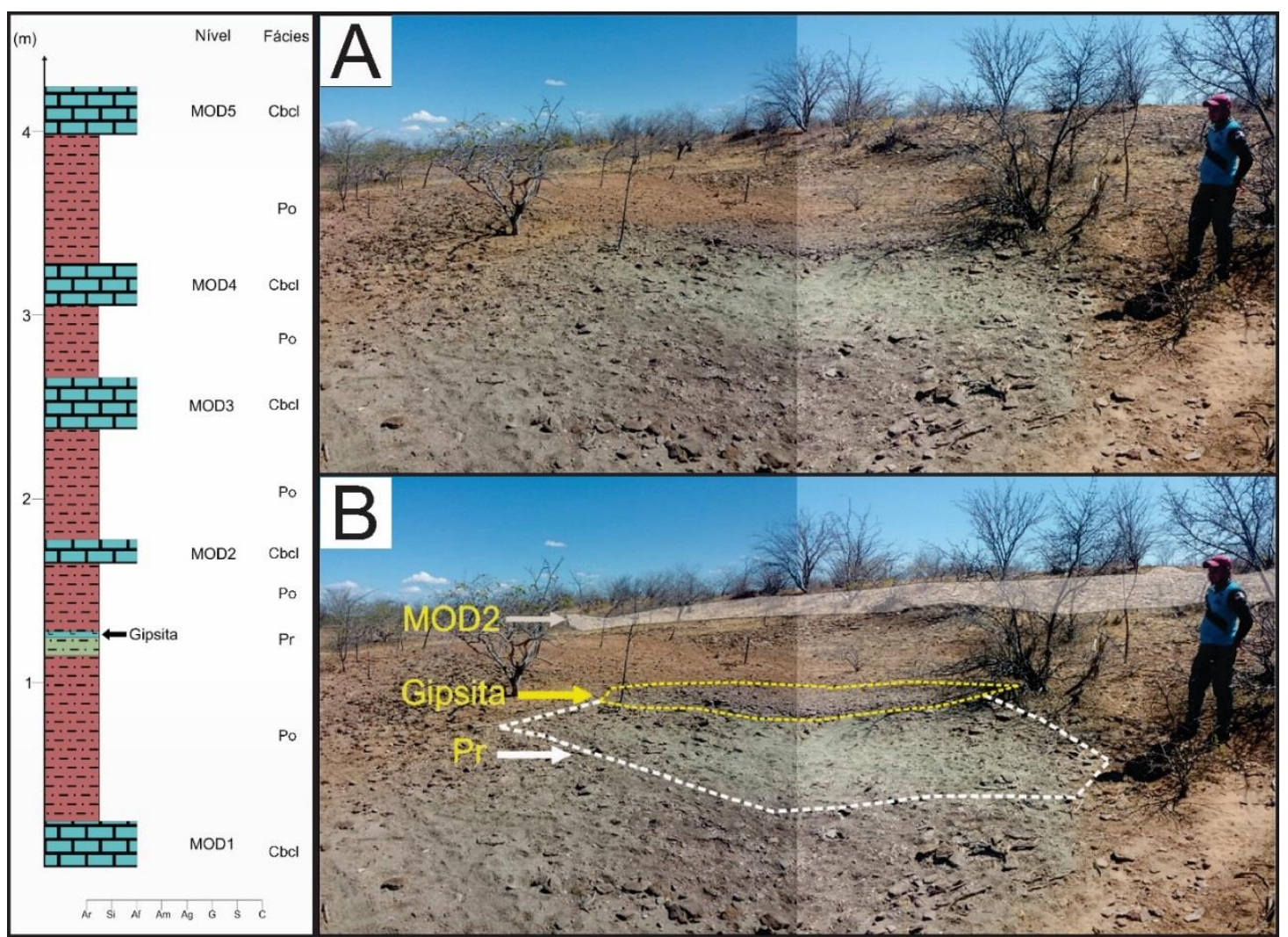

Figura 16. Seção Colunar do afloramento Modubim (coordenadas: 661780; 9056051) com pelitos argilosos a síltico-argilosos vermelho-castanho a arroxeados da litofácies $P o$, pelitos argilosos a síltico-argilosos verde a cinza esverdeado da litofácies $\mathrm{Pr}$, calcários e calcarenitos bioclásticos $\mathrm{Cbcl}$, calcários e calcarenitos não bioclásticos da litofácies $\mathrm{Ca}$ e lâminas de gipsita. A) Aspecto geral do afloramento Modubim da Formação Aliança. B) Interpretação do afloramento mostrando MOD2, uma camada de gispsita e os sedimentos esverdeados reduzidos.

As seções delgadas referentes às amostras da Formação Aliança apresentam forte semelhança. A lâmina do afloramento Macambira no nível carbonático 1 (MAC1) possui os mesmos componentes aloquímicos e material intergranular das amostras coletadas nos níveis carbonáticos do afloramento Modubim (MOD1, MOD2, MOD3, MOD4 e MOD5).

As rochas em questão têm origem autóctone e bioclástica, cujos principais constituintes aloquímicos são bioclastos e intraclastastos, dentre os quais esqueletos fósseis, carapaças e valvas desarticuladas/fragmentadas de conchostráceos, partículas terrígenas e fragmentos de sedimentos pouco consolidados da camada sotoposta.

O material intergranular é composto de cimento de calcita espática, massa homogênea de coloração parda, precipitado nos espaços porosos intergranulares $\mathrm{e}$ intragranulares originado a partir da degradação mecânica de esqueletos bioclásticos e posterior dissolução e recristalização. Segundo classificação de Dunham (1962), as características texturais apresentam-se como grainstone, com grãos compostos por esqueletos bioclásticos. A diferenciação entre os níveis carbonáticos se dá por sutilezas restritas à textura, como por exemplo a abundância e dimensões dos grãos bioclásticos, ou também pelo aumento de ocorrência de extraclastos.

Como exemplificação das informações acima temos a micrografia de um grainstone correspondente à ao calcário bioclástico MAC1 presente no afloramento Macambira (Fig. 17). Nele é possível ver a zona com grãos de quartzo em fração areia fina e bioclastos menores intercalados entre bioclastos em dimensões maiores, concordantemente com o aspecto da rocha em afloramento. 


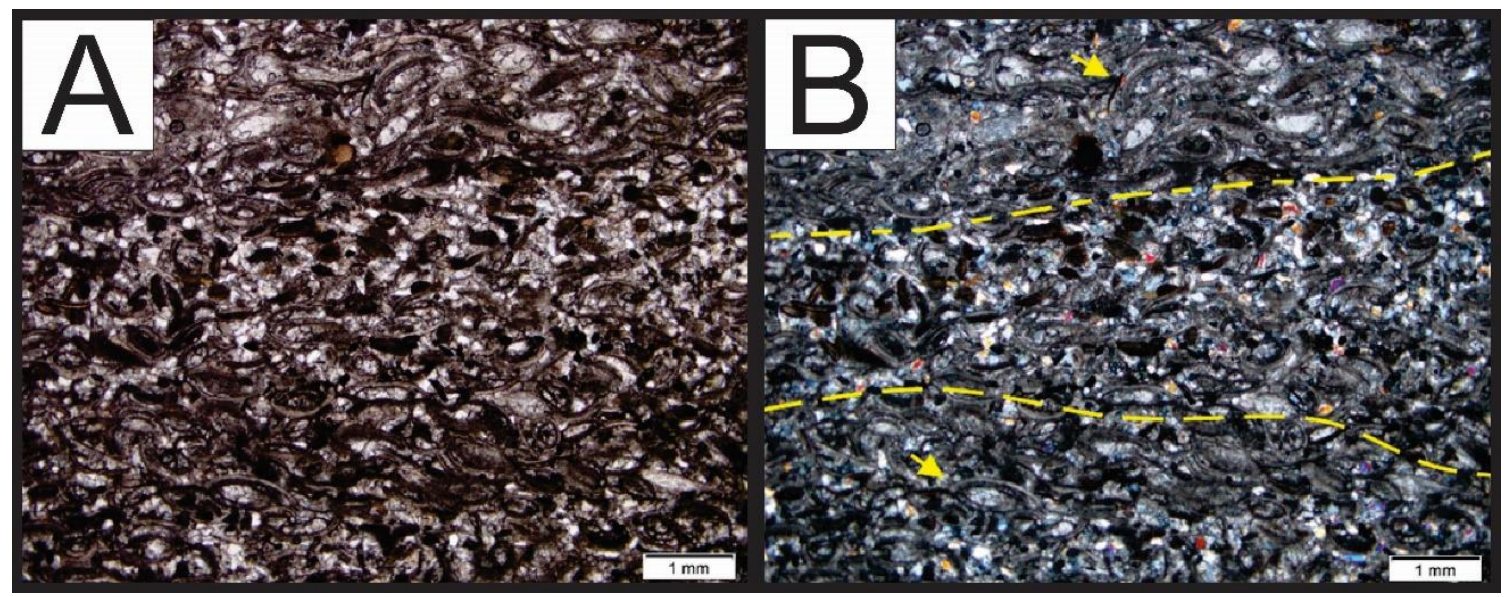

Figura 17. Fotomicrografia de lâmina da amostra do nível carbonático MAC1 à (A) Nicóis paralelos e (B) Nicóis cruzados. Linhas tracejadas mostram a zona com quartzo e bioclastos diminutos entre níveis de sedimentos mais grossos enquanto as setas apontam as carapaças de bioclastos maiores.

$\mathrm{Na}$ Figura 18 temos o detalhe de uma seção longitudinal de um grainstone correspondente a uma amostra do calcário bioclástico MOD3 presente no afloramento Modubim, com populosas e estreitamente compactadas carapaças articuladas de numerosos espécimes do gênero Ostracoda (seta amarela). No seu entorno há várias valvas desarticuladas. É possível ver o preenchimento das carapaças por material carbonático, uma vez que ao cruzar os nicóis e girar a platina é logo mostrada a geminação característica da calcita. A cimentação por ferro também se faz presente na amostra (seta azul).
A Formação Aliança é bastante conhecida pelo seu rico conteúdo fossilífero e por expressar uma paleontologia que marca um momento importante do Jurássico superior nas bacias em que se encontra. Macroscopicamente, é possível identificar diversas estruturas fossilíferas. Uma amostra contendo fóssil de dente com proporções significativas foi identificada (Fig. 19). Dadas as dimensões do exemplar em comparação a características de gêneros que ocorreram na época, entende-se que se trata de um dente de peixe do gênero Mawsonia.

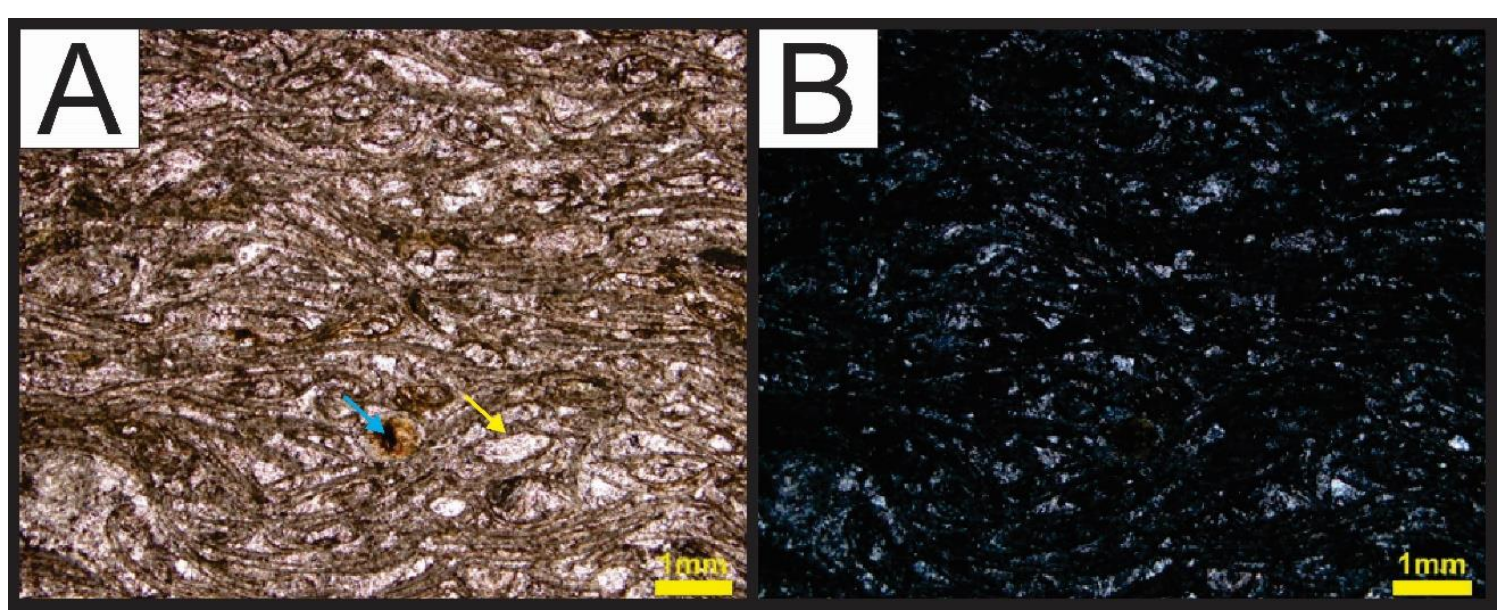

Figura 18. Fotomicrografia de lâmina da amostra do nível carbonático MOD3 à (A) Nicóis paralelos e (B) Nicóis cruzados. Carapaças estreitamente compactadas articuladas de Ostracoda (seta amarela) cercada de várias valvas desarticuladas. É possível ver o preenchimento das carapaças por material carbonático, uma vez que a nicóis é vista a geminação característica da calcita. A cimentação por ferro também se faz presente na amostra (seta azul). 


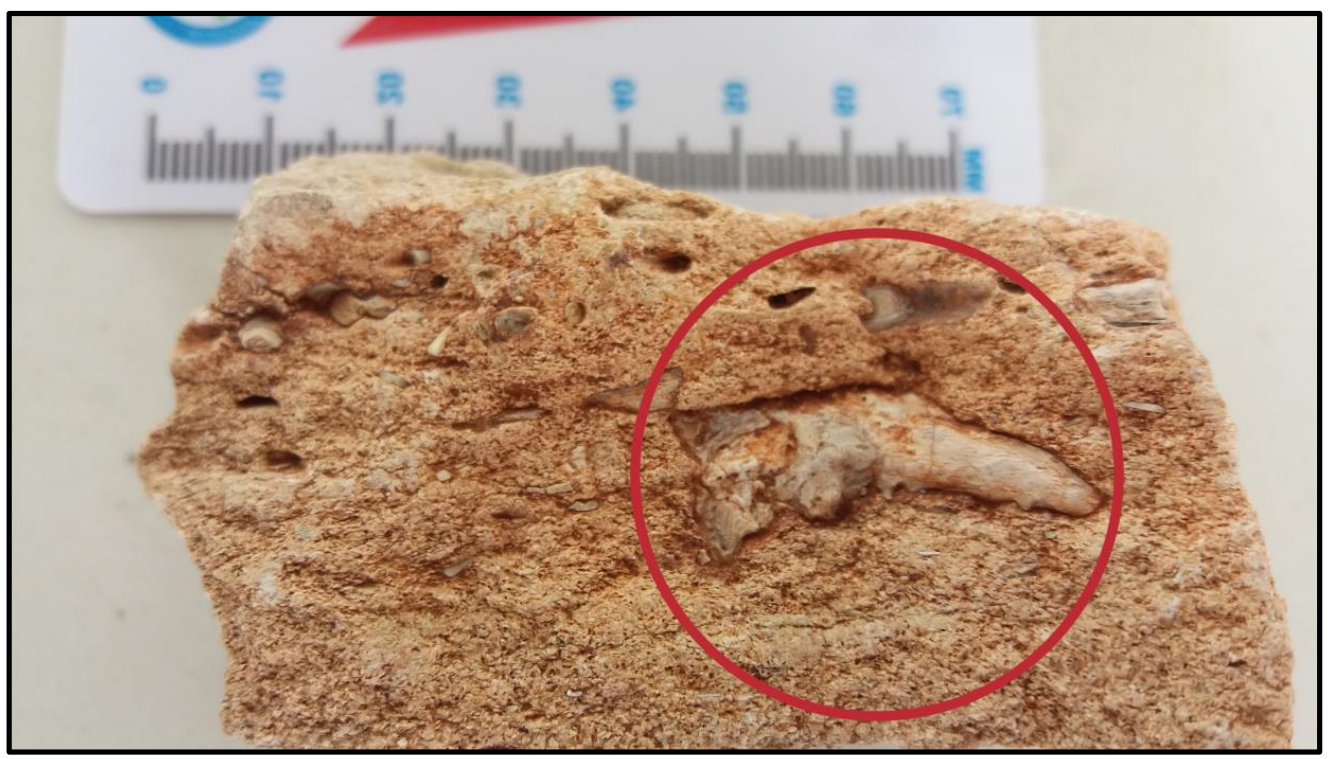

Figura 19. Dente fóssil de um peixe do gênero Mawsonia encontrado na Formação Aliança.

Os icnofósseis também são frequentes e por vezes marcam caminhos de locomoção ou até mesmo moldes de repouso (Fig. 20). Analisando a morfologia desses icnofósseis não foram obtidas características suficientes que pudessem ser comparadas e sugerissem um nome.

\section{Formação Sergi}

A Formação Sergi ocorre à centro sul do mapa, com pouca frequência na área estudada, frequentemente fazendo contato com Formação Aliança em regiões de relevo suave através de mudança brusca de coloração do solo. Podemos observar este contato mais claramente em afloramentos de ravinas, em que a base da Formação Sergi se separa do topo da Formação Aliança através de discordância erosiva, conforme a Figura 21.

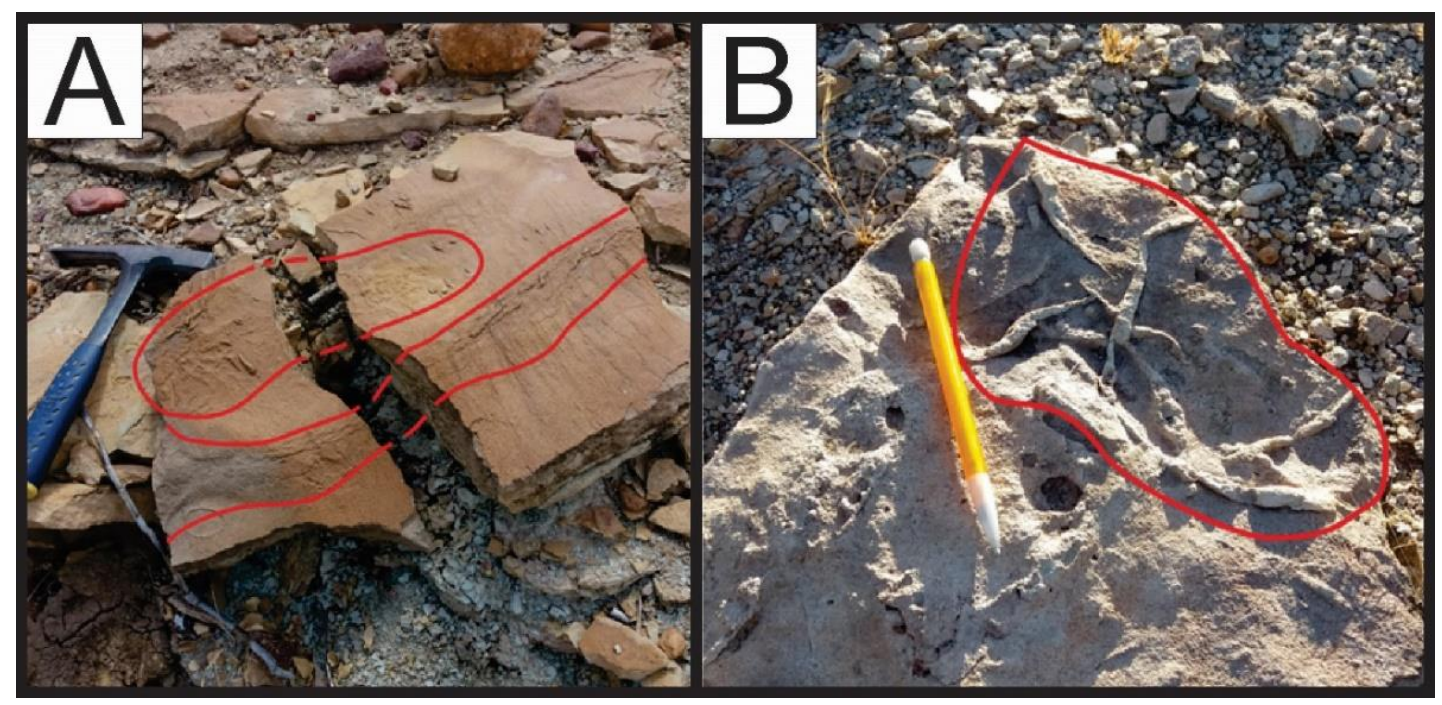

Figura 20. A) Vestígios de traços de espécies animais. B) Placa de calcário contendo abundantes icnofósseis na Formação Aliança. 


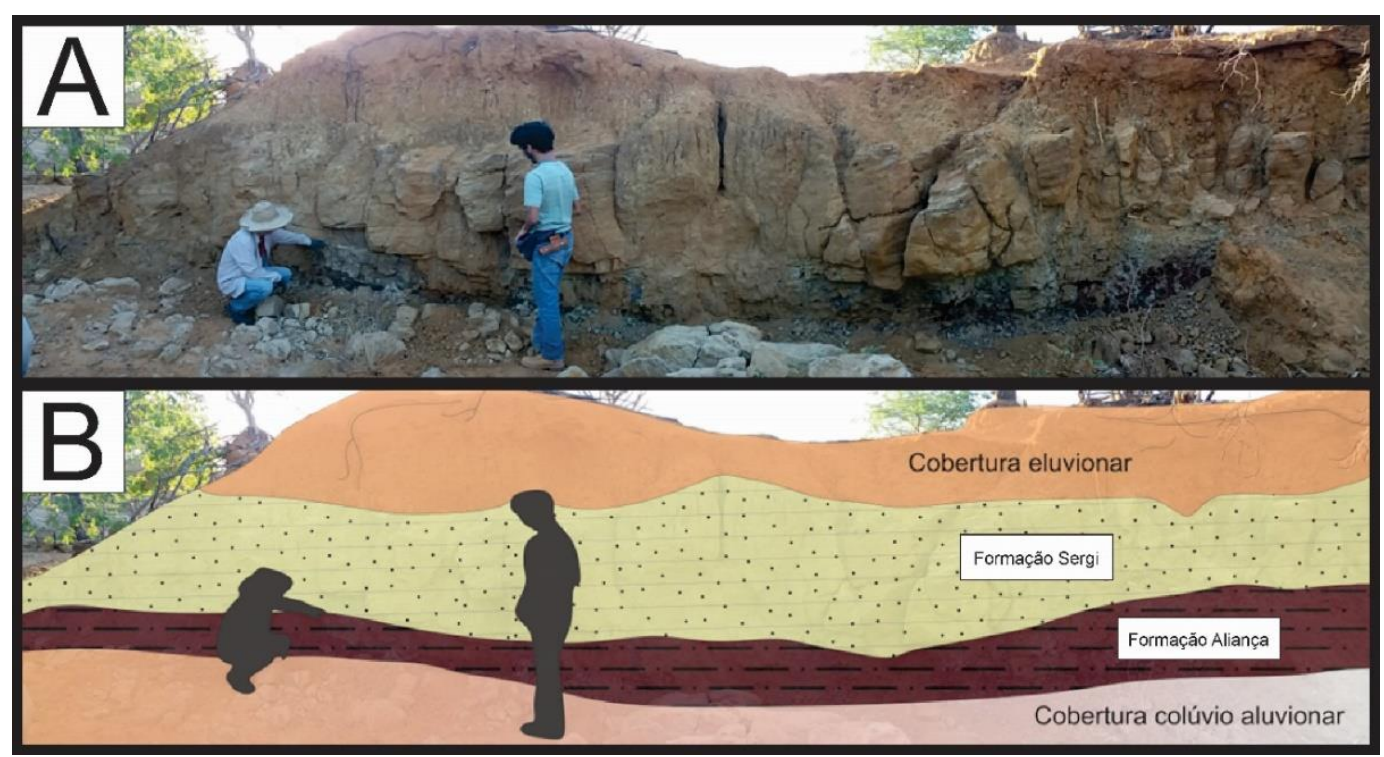

Figura 21. Afloramento apresentando contato entre as Formações Aliança e Sergi. (coordenadas: 663421; 9054715). A) Contato entre pelitos síltico-argilososos arroxeados e esverdeados do topo da Formação Aliança e arenitos médios a grossos castanhos a alaranjados da base da Formação Sergi através de discordância erosiva num corte visto em ravina. B) Interpretação geológica da seção descrita destacando ainda as coberturas quaternárias.

Esta formação é representada por arenitos médios a grossos de colorações que variam entre o creme esbranquiçado a acinzentando além de alaranjado. Em alguns percebe-se uma granodecrescência ascendente, podendo ocorrer níveis conglomeráticos nas porções mais grossas com grânulos dispersos. A depender do afloramento e sua maturidade, acontecem variações na coloração, assim como no tamanho de grão em algumas estruturas denotando pobre seleção.

Em regiões topograficamente mais elevadas verificam-se afloramentos de arenitos maciços cinza claros, com tamanho de grão correspondente a areia fina a média, bem compactados e supermaturos (Fig. 22A). Há zoneamentos de coloração alaranjada nos arenitos cuja gênese está associada a percolação de fluidos ricos em óxido e hidróxido de ferro, resultando em sua integração à cimentação da rocha. Em toda a superfície do afloramento são encontrados blocos rolados de dimensões variadas que estão abundantemente concentrados na base (Fig. 22B). Esses têm origem própria Formação Sergi e a formação sobreposta que foi desintegrada e transportada ao sopé por deslizamento pela ação da gravidade, compondo um depósito de Tálus. 


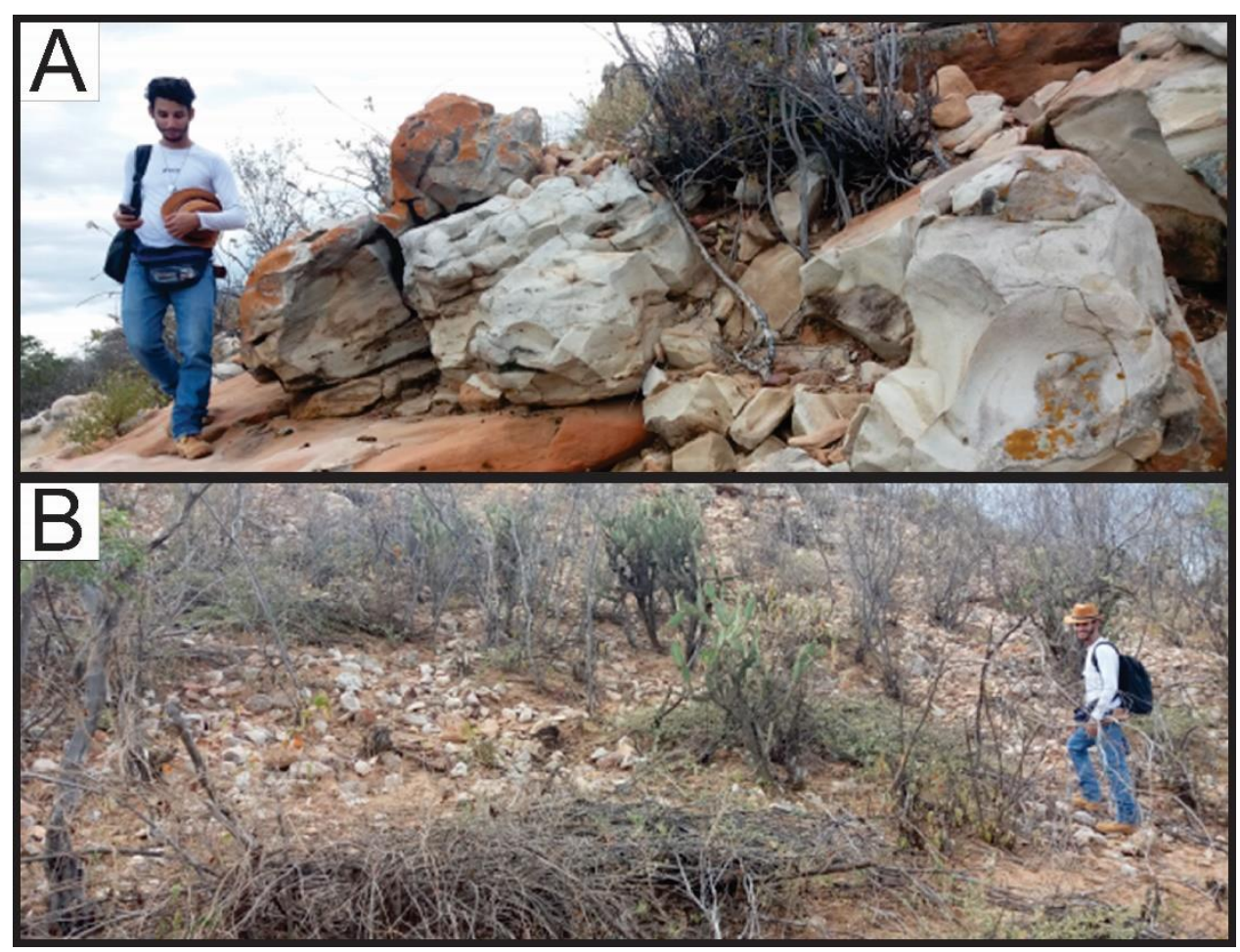

Figura 22. A) Afloramento da Formação Sergi contendo arenitos médios a grossos, creme esbranquiçados a acinzentados e alaranjados, com granodecrescência ascendente e grânulos dispersos. B) Blocos rolados da Formação Sergi com dimensões variadas abundantemente encontrados no sopé de morrotes próximos ao afloramento da mesma formação (coordenadas: $658250 ; 9058063)$

Foram encontrados, junto aos blocos, fragmentos de tronco fóssil (Fig. 23A), fortalecendo a interpretação de se tratar da Formação Sergi. Os fragmentos de tronco encontrados mostram os canais resinosos e anéis de crescimento, preservados por petrificação das paredes e permineralização dos espaços celulares por sílica, conforme a Figura 23B.

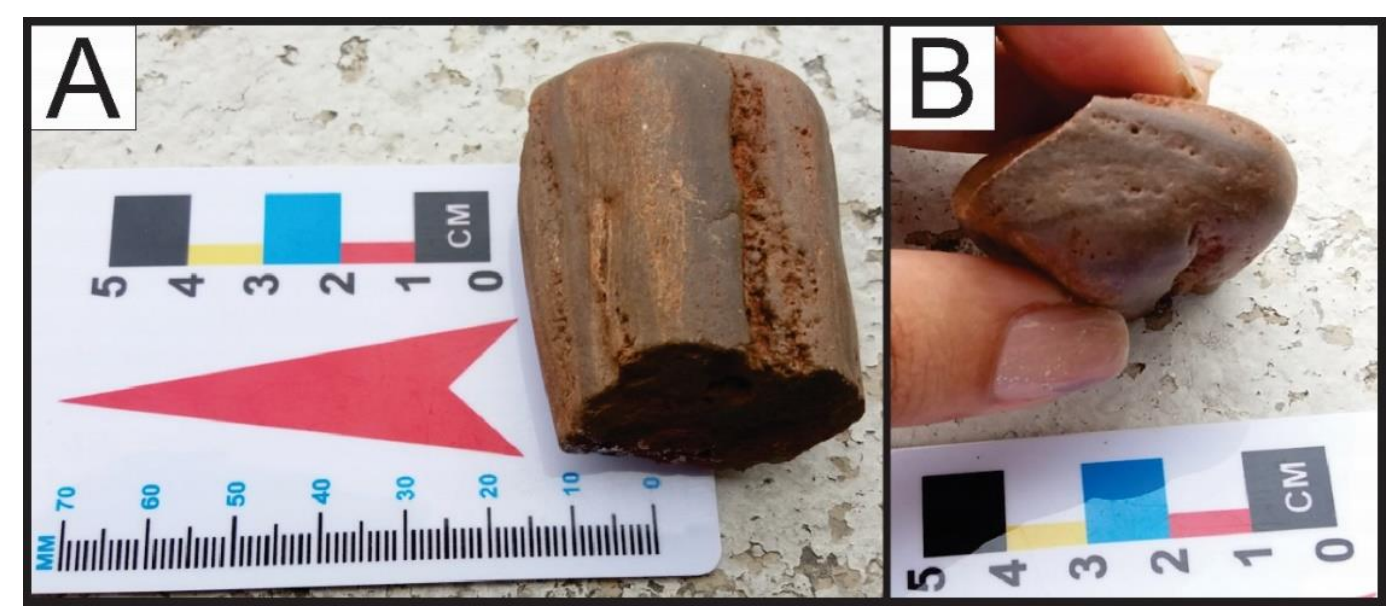

Figura 23. A) Fragmento de tronco fóssil encontrado em afloramentos da Formação Sergi com canais resinosos e anéis de crescimento preservados por petrificação das paredes e permineralização dos espaços celulares por sílica, cujas dimensões foram medidas como 5,2 x 4,0 x 2,1cm, B) Detalhamento dos anéis de crescimento na seção interior do fragmento de tronco fóssil. 
Outro afloramento representativo foi o que o contato com a Formação Aliança exposto em ravina se mantém preservado, conforme a já citada Figura 37. Nesse afloramento a coloração adquire tons de marrom acinzentado, o tamanho de grão varia entre areia média e fina e as estruturas de deposição são bem visíveis. Na parte superior do pacote dessa unidade, são encontradas estratificações cruzadas planares com sets de pouca espessura e limites sub-horizontais bem demarcados, além de estratificações de alto ângulo (Fig. 24). São encontrados grânulos disseminados no arenito, demonstrando sua pobre seleção.

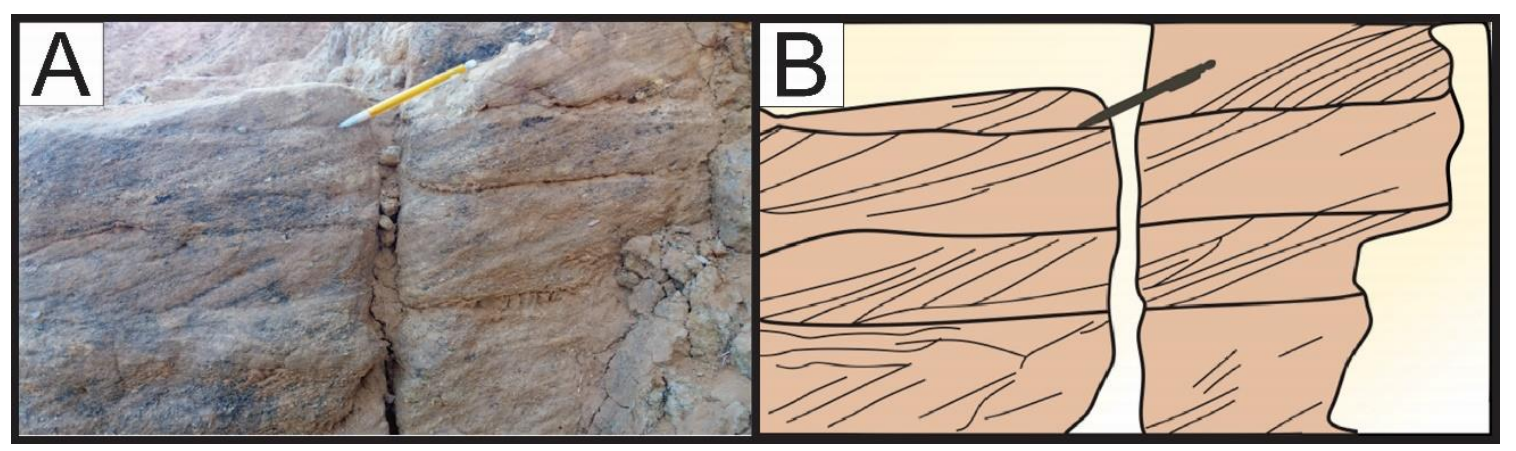

Figura 24. Estratificação cruzada planar do afloramento em ravina da Formação Sergi, demonstrando sets com superfícies limitantes sub-horizontais. (coordenadas: 663421; 9054715)

$\mathrm{Na}$ parte inferior do pacote, a estratificação acanala-se, os limites dos sets perdem seu paralelismo e os estratos tangenciam. O tamanho de grão é menor do que o encontrado no topo. Assim mostra a Figura 25, com foto do afloramento e interpretação mostrando várias superfícies de reativação.

Os demais afloramentos mostram uniformidade com as descrições acima. Embora a coloração alcance tonalidades laranja avermelhadas, como resultado da infiltração de óxido e hidróxido de ferro na cimentação, os padrões estruturais e granulométricos são similares. Há arenitos médios a grossos, mal selecionados e com granocrescência ascendente e estratos com sets curvos caracterizando estratificações cruzadas acanaladas com superfícies de reativação (Fig. 26A). Há ainda seixos disseminados mal selecionados em níveis conglomeráticos (Fig. 26B). No topo a estratificação é mais sutil, no entanto se mostra cruzada e trunca ao encontro de outro estrato. Na região basal do afloramento o arenito fino apresenta acamamento planar com atitude de 280/40.

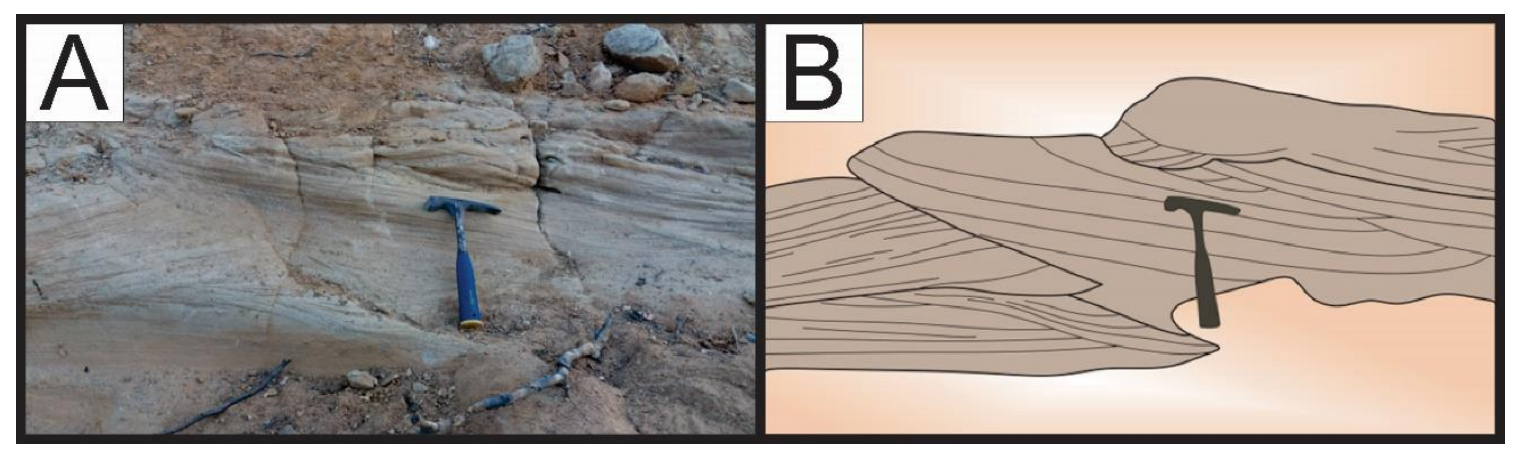

Figura 25. Base do pacote de rocha com menores tamanhos de grãos e estratificação cruzada acanaladas. Destaca-se o não paralelismo da base dos sets em oposição ao encontrado na porção de topo do mesmo afloramento. 


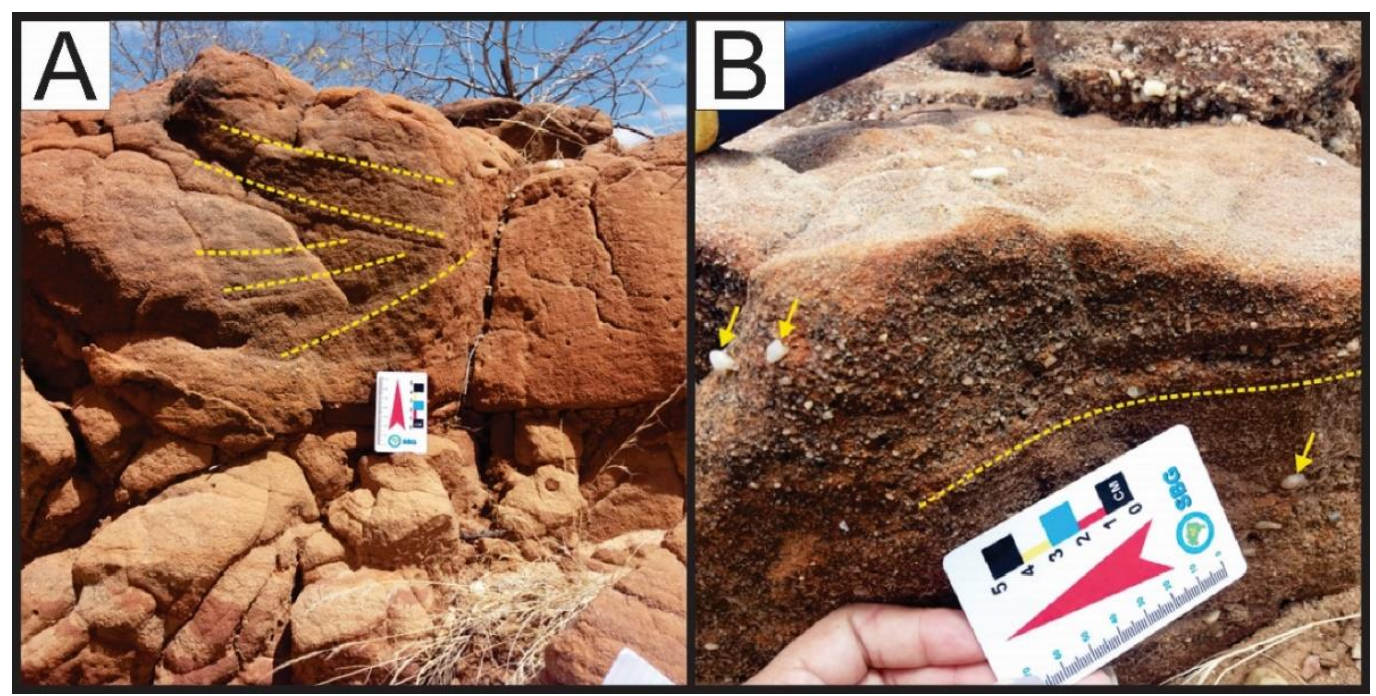

Figura 26. A) Arenitos da Formação Sergi médios a grossos, mal selecionados e estratificações cruzadas acanaladas com superfícies de reativação (coordenadas: 660733; 9056788); B) Seixos disseminados de aproximadamente $1 \mathrm{~cm}$ (seta amarela) e níveis conglomeráticos (linha tracejada).

A petrografia dos arenitos de topo mostra grãos de areia grossa a muito grossa, compostos majoritariamente por quartzo, subarredondados e de baixa esfericidade. Eles fazem contatos pontuais e côncavoconvexo. É moderadamente selecionado, com espaços vazios abundantes e por vezes preenchidos por cimento carbonático. Verificam-se grãos de quartzo policristalino e geminação ondulante que indicam a ocorrência de rochas metamórficas na área fonte (Fig. 27).

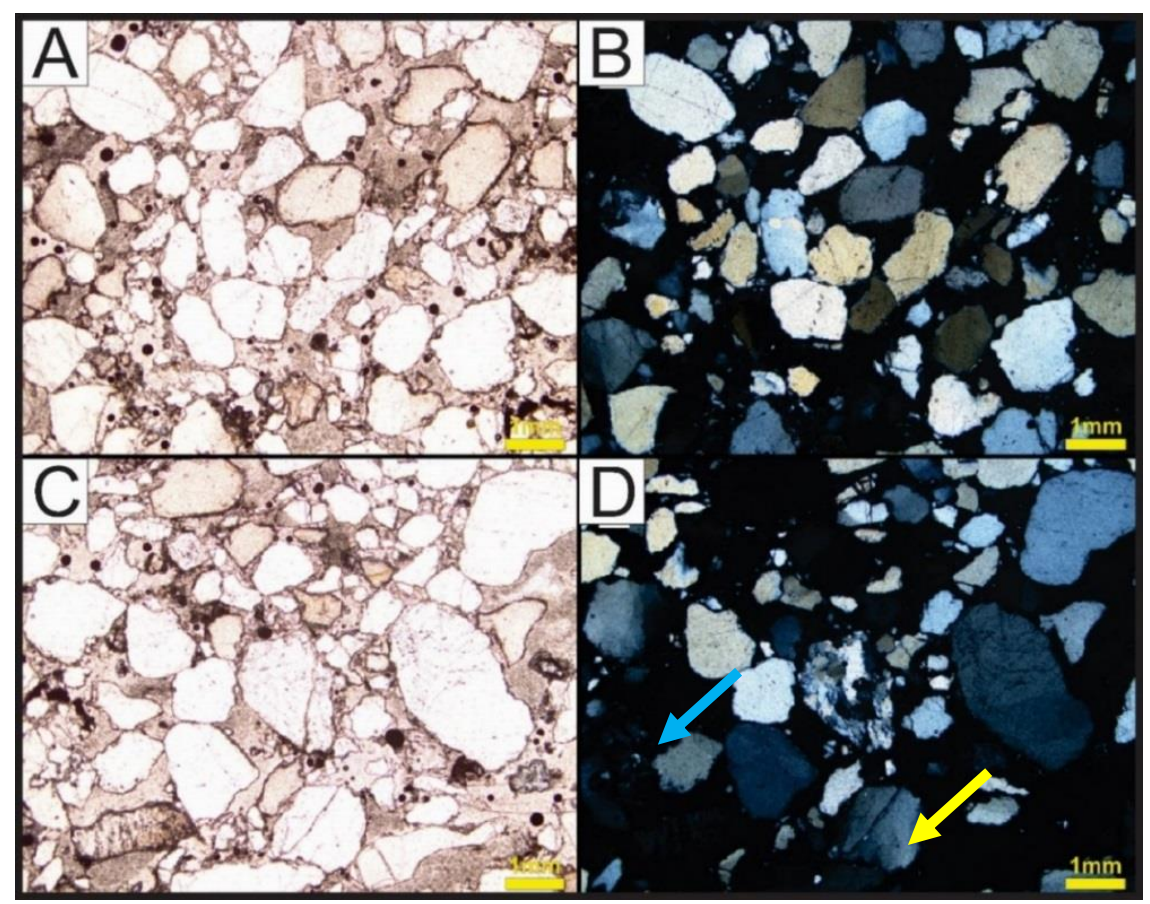

Figura 27. A) Grãos subarredondados com baixa esfericidade e espaços intergrãos preenchidos por cimentação carbonática observados a nicóis paralelos. B) Observação anterior à nicóis cruzados. C) Grãos de quartzo subarredondados. D) Visão anterior a nicois cruzados, detalhe do quartzo policristalino (seta amarela) e geminação ondulante (seta azul) indicando origem metamórfica dos grãos de quartzo. 
A petrografia dos arenitos da base do afloramento indica grãos de areia fina a média e igualmente compostos quase que totalmente por quartzo. Alguns grãos encontrados pertencem à série do feldspato potássico, com típica geminação de microclina. São angulosos e um pouco esféricos, contém empacotamento mais fechado e espaços vazios raros. A seleção é moderada a boa (Fig. 28).

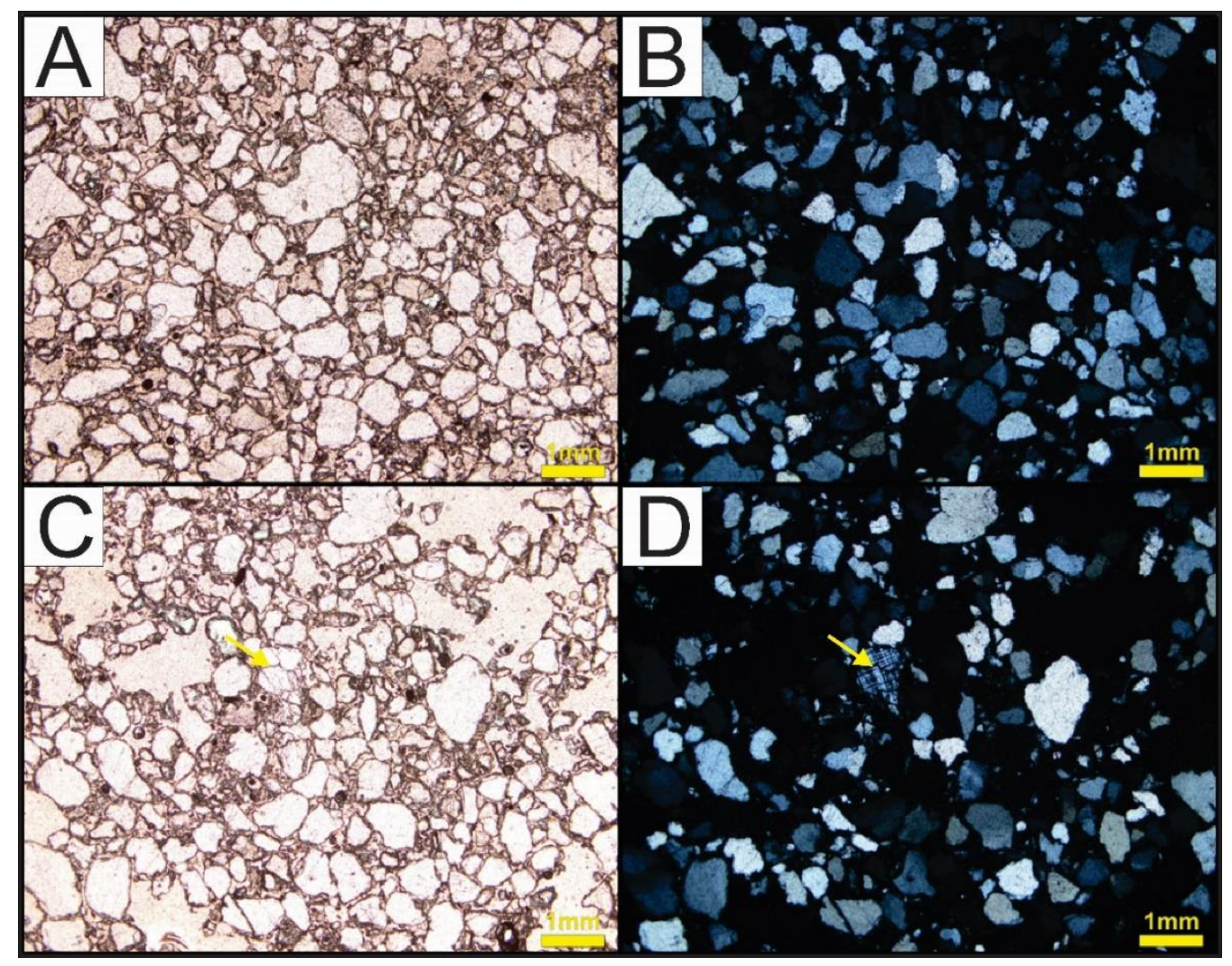

Figura 28. A) Fotomicrografia a nicóis paralelos mostrando moderada a boa seleção de grãos angulosos e subangulosos com baixa esfericidade médios a finos de quartzo com frequentes contatos pontuais e côncavo-convexos entre os grãos. B) Igual seção a nicóis cruzados. C) Seta amarela destacando a presença de grão de feldspato potássico com geminação característica da microclina em meio aos grãos de quartzo. D) Igual seção a nicóis cruzados.

A Formação Sergi ocorre sobreposta à Formação Aliança, à qual está sobreposta, marcando um ambiente flúvio-eólico na Bacia de Jatobá no Jurássico em pleno início de rifte.

\section{Formação Candeias}

As ocorrências da Formação Candeias estão distribuídas ao longo de uma faixa alongada de direção NNW-SSE. É sobre esta unidade que está inserido o povoado de Campos. Os afloramentos são expostos como áreas arrasadas, em razão do caráter dominantemente pelítico e finamente arenoso. Também é importante ressaltar que nessa formação estão inseridos pequenos povoados, por isso a modificação antrópica é bastante frequente. Desse modo as rochas foram melhor visualizadas e descritas em ravinas encontradas em canais secos onde corre fluxo intermitente de água.

A litologia desta unidade compreende argilitos e siltitos argilosos de coloração creme e róseo avermelhadas. Há intercalação desses horizontes com arenitos finos, calcíferos e as vezes fossilíferos, geralmente rígidos, porém sob a forma mais friáveis nas camadas mais superficiais.

Ocorre na região afloramentos que mostram contato erosivo entre a Formação Candeias e aquela estratigraficamente sobreposta a ela, a Formação São Sebastião, conforme a Figura 29 


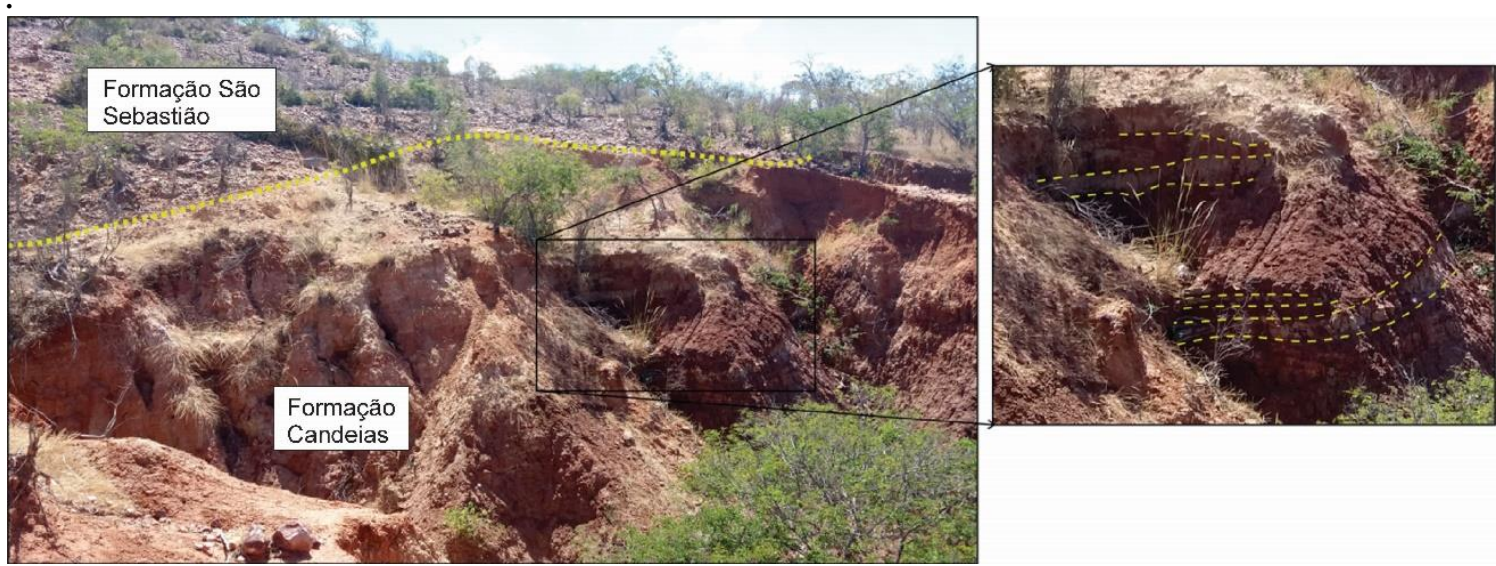

Figura 29. Afloramento de contato erosivo entre Formações Candeias e São Sebastião (coordenadas: 658427; 9054466). A linha pontilhada marca o limite entre os argilitos com níveis de arenito creme no topo da Formação Candeias e os arenitos creme avermelhados, superficialmente cobertos por sedimentos inconsolidados na base da Formação São Sebastião. Em detalhe é mostrada a rocha inferior e as linhas tracejadas marcam os níveis de arenito.

\section{Formação São Sebastião}

Os afloramentos da Formação São Sebastião são vistos em formas geomorfológicas de serras arredondadas e morrotes ondulados, ou em menor quantidade, serras escarpadas (Fig. 30), e estão distribuídas na parte oeste da área de estudo. É comum encontrar depósito de tálus no sopé desses altos topográficos, compostos de blocos rolados com dimensões variadas resultado da desagregação de unidades estratigraficamente superiores, hoje erodidas (Fig. 31)

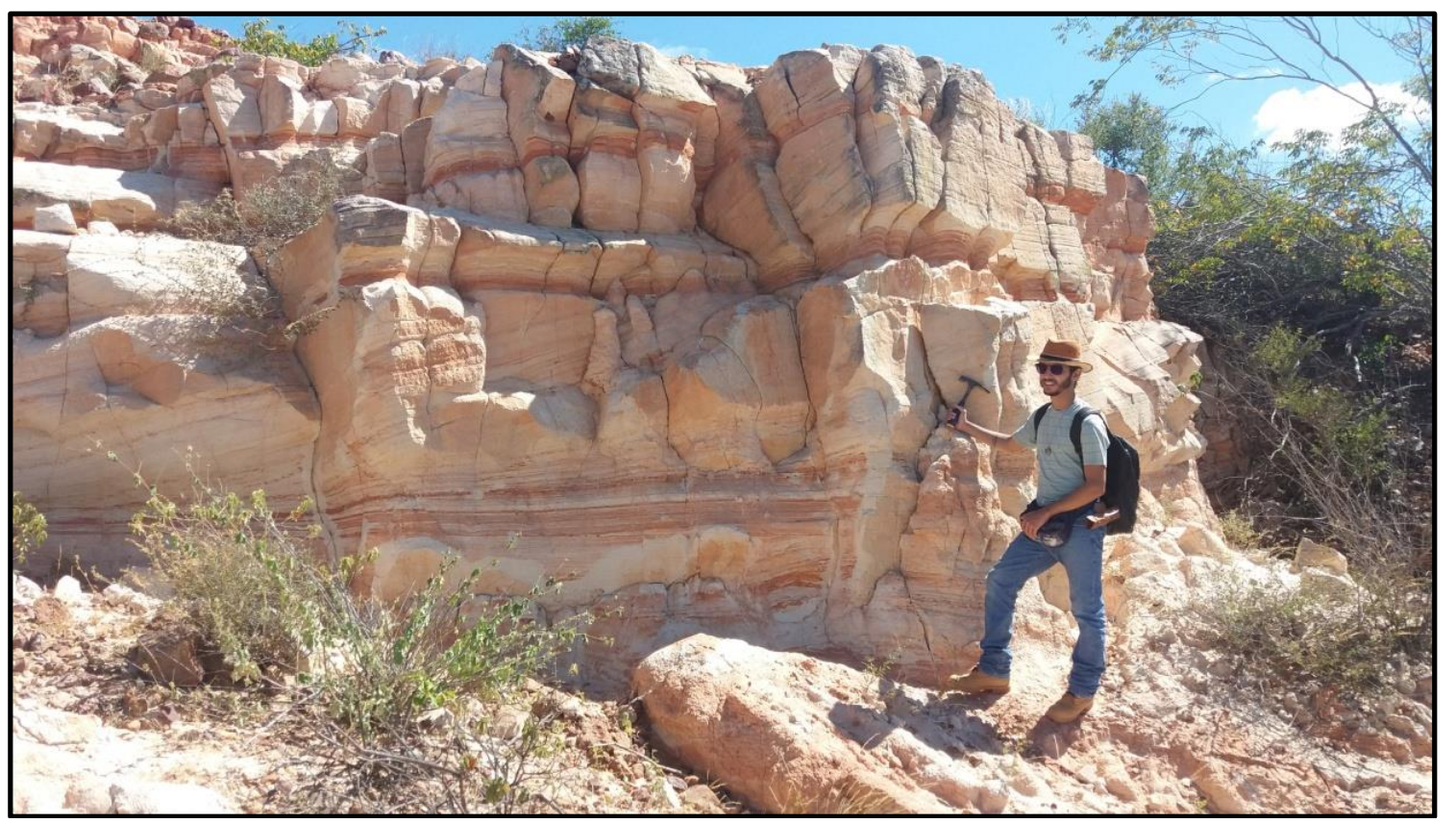

Figura 30. Visão geral dos arenitos médios a muito finos, de coloração creme a alaranjado com estratificações cruzadas sob-relevo escarpado da Formação São Sebastião (coordenadas: 658351; 9051529). 


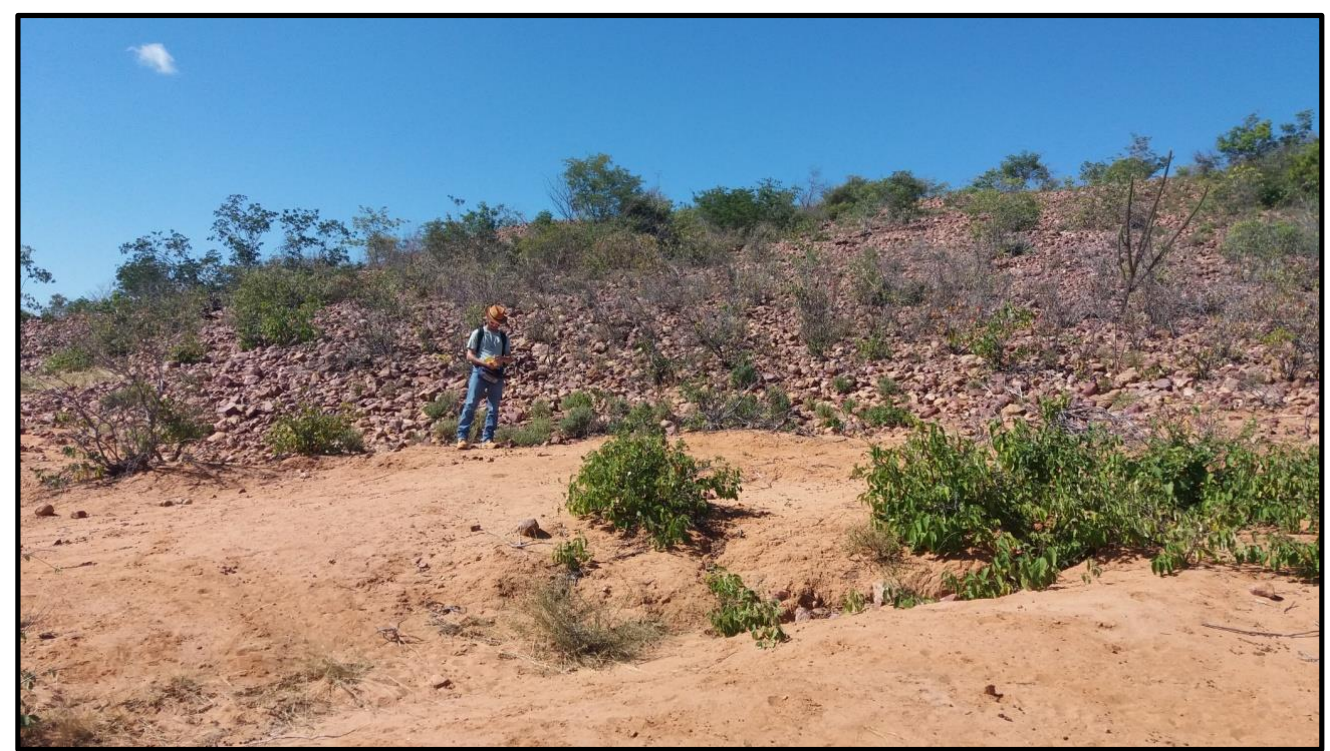

Figura 31. Depósito de Tálus no sopé de morrotes compostos de blocos rolados com dimensões variadas resultado da desagregação das demais formações próximas (coordenadas: 658055; 9054982).

A litologia corresponde a arenitos médios a muito finos, de coloração variando entre o creme ao alaranjado intenso. $\mathrm{Na}$ maioria dos afloramentos a rocha é pouco coesa. São encontradas estratificações planoparalelas (Fig. 32) como também cruzadas de alto ângulo.

As rochas são frequentemente bimodais, geradas por intercalação de tamanhos de grãos distinta. Esse fenômeno é resultado de fluxo de grãos (grainflow) e queda de grãos (grainfall). Quando pequenas avalanches de areia descem a face de sotavento (lee-side) da forma de leito, os estratos cruzados ali depositados mostram boa seleção e gradação inversa, isto é, com partículas mais grossas concentradas em direção à parte superior de cada estrato. Os estratos de grãos mais grossos e mais espessos depositados pelas avalanches e pela tração frequentemente alternam-se com estratos mais delgados de material com grãos mais finos depositados por suspensão.

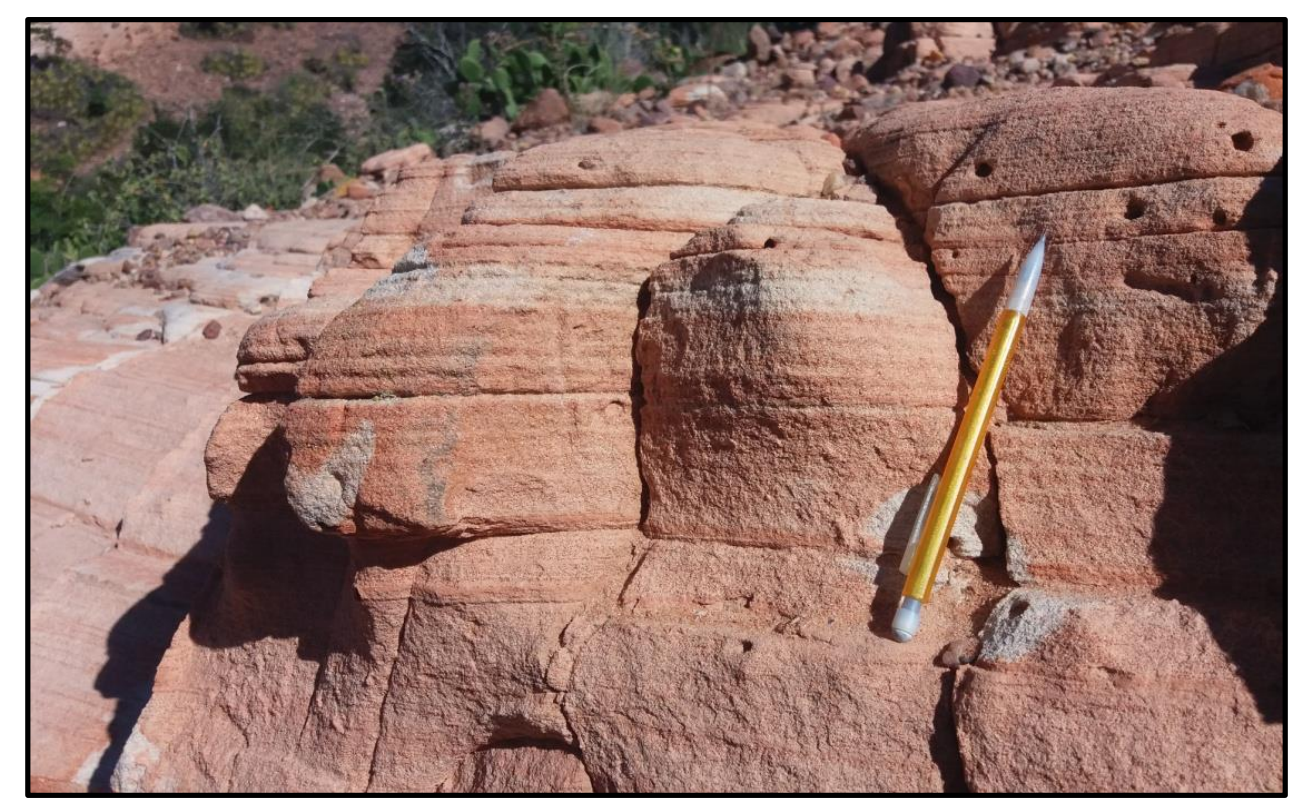

Figura 32. Estratificação plano paralela em arenito bimodal da Formação São Sebastião (coordenadas: 658351; 9051529). 
São comuns a esses afloramentos as estratificações cruzadas acanaladas de grande porte e alto ângulo com paleocorrentes indicando diversos sentidos do fluxo sedimentar. Esta característica é típica de sedimentação sob-regime de ambientes eólicos. Essa interpretação é reforçada pela morfologia dos afloramentos como paleodunas (Fig. 33).

Dentro dos pacotes de deposição eólica, encontram-se estruturas em paleocanais, que são reconhecidas pela relação de truncamento com os sedimentos subjacentes. Estes canais, vistos em corte, contêm estratificação acanalada e preenchimento formando corpos sedimentares alongados com concavidade para cima. O interior desses canais está preenchido por sedimentos de maior tamanho de grão, intraclastos laminados das rochas adjacentes e seus sedimentos são mais pobremente selecionados quando comparados com os que compõem as rochas das camadas contíguas (Fig. 34).

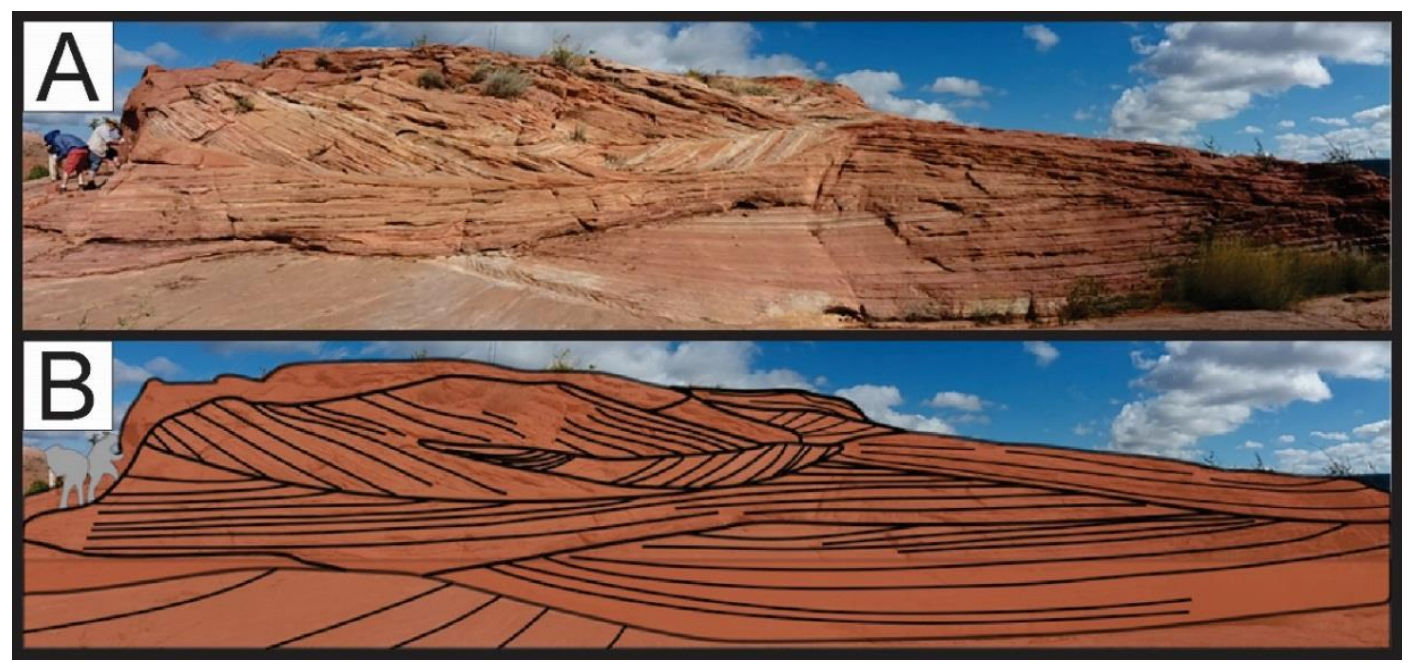

Figura 33. Panorama de paleodunas em afloramentos da Formação São Sebastião contendo amalgamento de múltiplos elementos arquiteturais contíguos (coordenadas: 654269; 9057549).

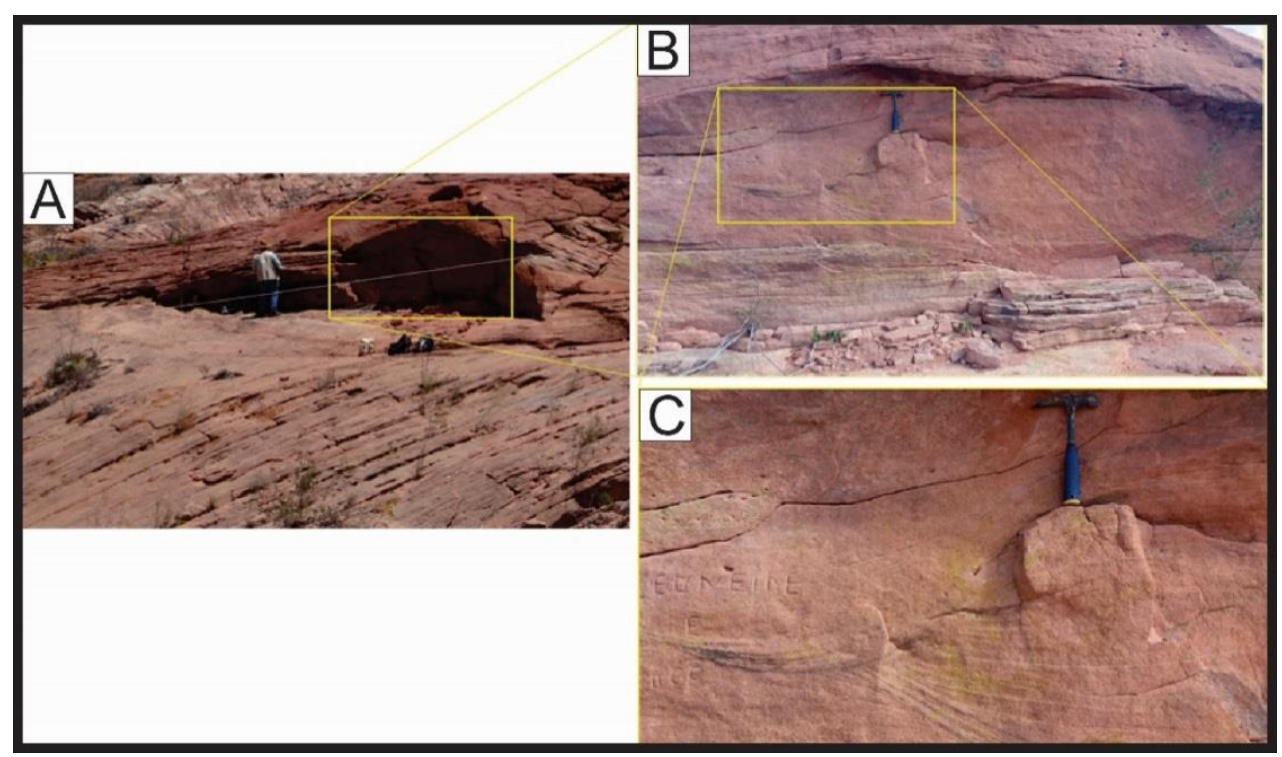

Figura 34. A) Detalhamento de afloramento da Formação São Sebastião contendo intercalação entre palodunas amalgamadas com estrutura de paleocanal (coordenadas: 654269; 9057549). B) 
Vista do interior do paleocanal. C) Detalhamento da estratificação acanalada de migração de canal no interior do paleocanal (coordenadas: 654269; 9057549).

Com base nas informações adquiridas em campo foi possível confeccionar uma seção colunar mostrando as relações de espessura e características estruturais do afloramento e valores de paleocorrentes (Fig.

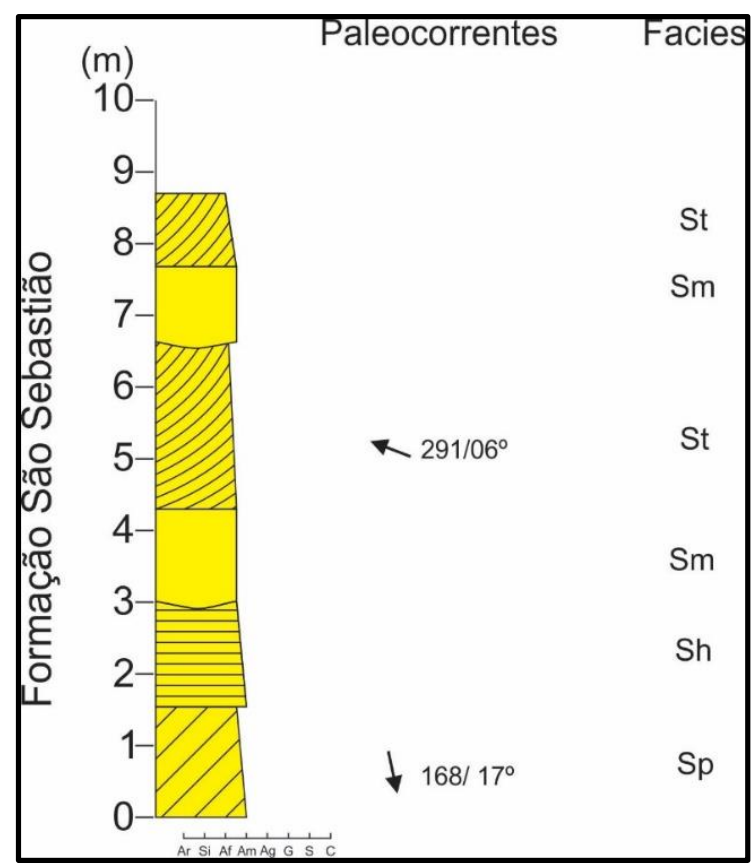

Seções delgadas do depósito de duna apresentam grãos de quartzo com tamanho de grão correspondente a areia fina a média com morfologia subangulosa e baixa esfericidade,
35). Nele constam 3 litofácies distintas, são eles os arenitos médios a finos, bem selecionados, bimodais, avermelhados com presença de estratificação planar $S p$. Arenitos médios a finos, bem selecionados, bimodais, avermelhados com presença de estratificação cruzada acanalada St. Arenitos médios a finos, moderadamente selecionados, avermelhados maciços $\mathrm{Sm}$.

Figura 35. Seção colunar do afloramento contendo arenitos médios a finos, bem selecionados, bimodais, avermelhados com presença de estratificação planar da litofácies $S p$. Arenitos médios a finos, bem selecionados, bimodais, avermelhados com presença de estratificação cruzada acanalada correspondente a litofácies St. E enfim os arenitos médios a finos, moderadamente selecionados, avermelhados maciços $\mathrm{Sm}$

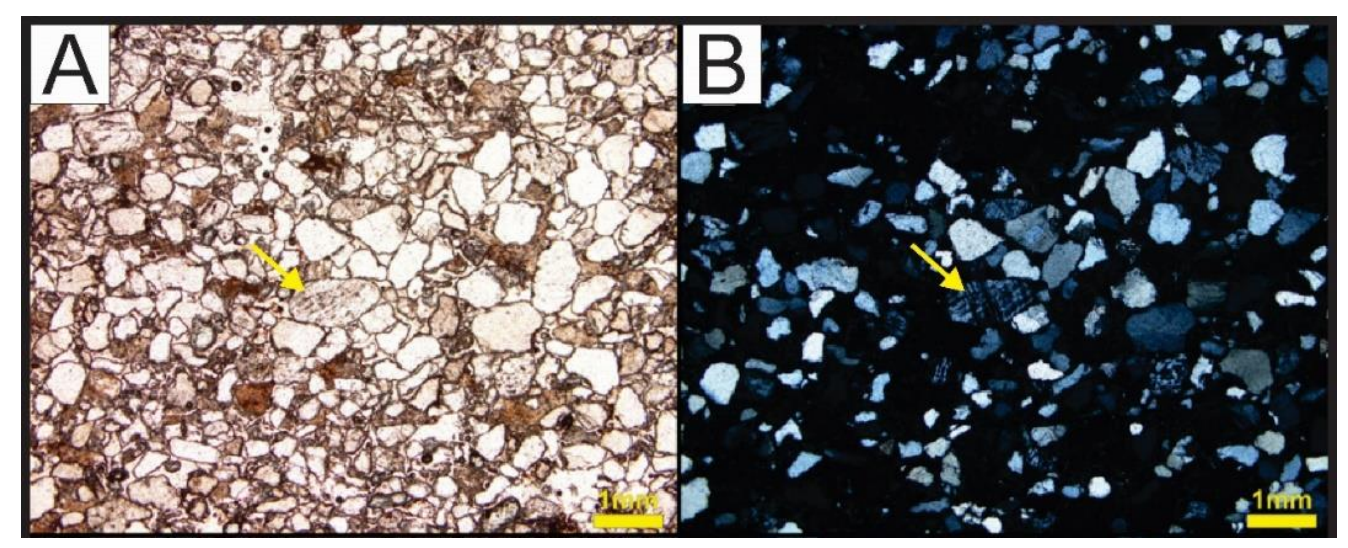

Figura 36. A) Fotomicrografia a nicóis paralelos dos depósitos de duna da Formação São Sebastião mostrando os grãos de quartzo na fração areia fina a média com contatos retos e côncavoconvexos. Em destaque temos um dos raros grãos de feldspato (seta amarela). B) Observação anterior à nicóis cruzados.

boa seleção e empacotamento denso, fazendo contatos retos e côncavo-convexos uns com os outros. Grãos de feldspato potássico são raros, conforme a Figura 36. 
As seções delgadas de depósito de canal mostram grãos de quartzo numa fração de areia grossa a muito grossa, contendo grãos menores subordinadamente os quais compõem uma matriz que preenche os espaços entre os grãos maiores. Os sedimentos poucas vezes fazem contato entre si, mas quando ocorrem eles são côncavoconvexos e retos. De forma geral apresentamse em formas subarredondadas e esféricas, porém, pobremente selecionados. Há muitos espaços intergrãos, alguns deles são preenchidos por material de coloração parda resultante de uma cimentação carbonática (Fig. 37).

A diferença granulométrica e de seleção das duas amostras são bastante consideráveis. $\mathrm{O}$ aumento na granulometria está associado a uma influência do regime de energia superior ocorrido. Dessa forma o ambiente deposicional é eólico com influência fluvial de alta energia. Com sedimentação de depósitos de duna, onde canais fluviais de pequeno porte remobilizaram as camadas mais superficiais, arrancando clastos e empobrecendo a seleção

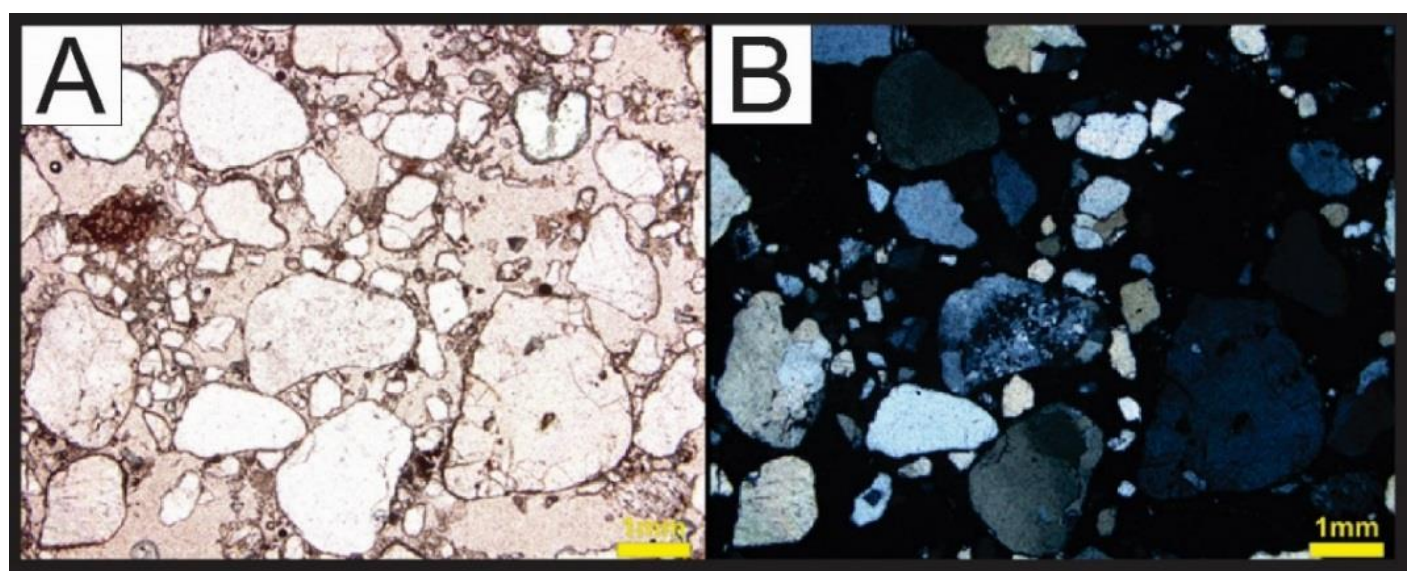

Figura 37. A) Fotomicrografia da porção de depósito de canal da Formação São Sebastião, mostrando grãos de quartzo em fração areia grossa a muito grossa, pobre seleção, subarredondados com espaços intergrãos preenchidos parcialmente por óxido de ferro e esparsos contatos côncavoconvexos e retos. B) Observação anterior a nicóis cruzados.

\section{Coberturas Quaternárias}

As coberturas quaternárias são representadas por sedimentos inconsolidados colúvio-eluvionares e os depósitos relacionados a aluviões. Em vários locais dentro do perímetro de estudo ocorrem vastas áreas onde se concentram estes depósitos de areia fina a muito fina. Eles recobrem regiões planas, as vias de acesso e sopés de afloramentos, estando associados a blocos soltos da formação aflorante ou das formações superiores.

Depósitos aluvionares são vistos sobre leito e planície de inundação de canais secos de fluxo intermitente, conforme a Figura 38. Nesses canais predominam o tamanho de grão correspondente a areia fina a média, mas subordinadamente são vistos grânulos e blocos de origens diversas, assegurando a má seleção característica desses tipos de depósitos.

\section{DISCUSSÃO E CONCLUSÕES}

O conteúdo deste artigo representou de forma detalhada o mapeamento geológico ocorrido na porção do extremo nordeste da Folha SC.24-X-A-VI Poço da Cruz, pertencente ao município de Ibimirim, NE brasileiro. Seu produto final foi o mapa em escala de 1:50.000 mostrando 7 unidades litoestratigráficas distintas: a Formação Tacaratu (SDt), a Formação Inajá (Di), a Formação Aliança (J3a), Formação Sergi (Js), Formação Candeias (K1ca), Formação São Sebastião (K1ss) e as Coberturas Quaternárias (Qc). 


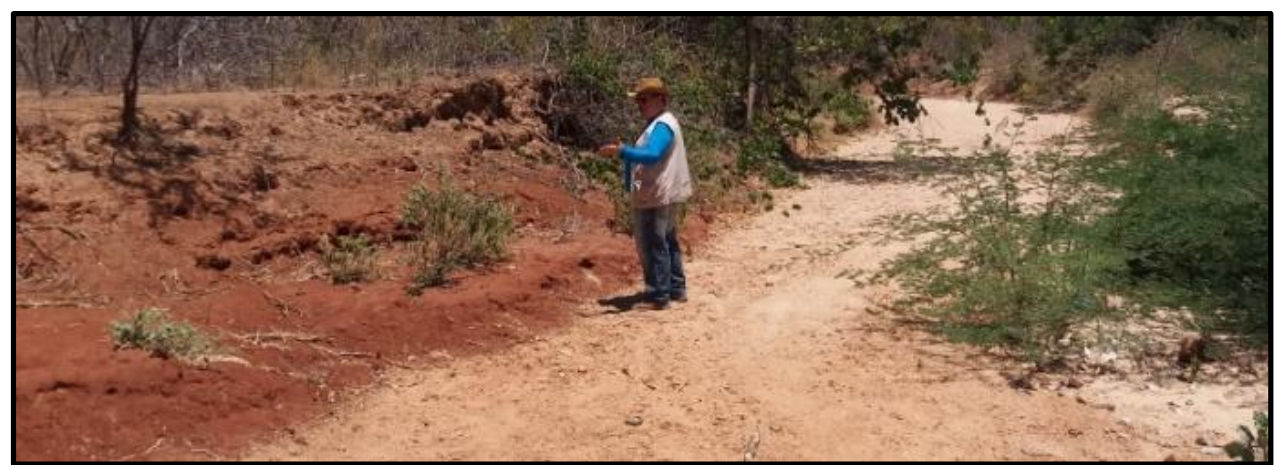

Figura 38. Depósito aluvionar depositado sobre leito de canal de fluxo intermitente contendo areia fina a média, mal selecionada com grânulos e blocos de origens diversas (coordenadas: 660589; 9056280).

As unidades encontradas que compõem a sequência de Início de Rifte (Formação Aliança e Formação Sergi), a quem foram dirigidas maior atenção neste trabalho, estão orientadas em um trend $\mathrm{N}-\mathrm{S}$ e se mostram um tanto mais espessas em planta do que nos mapeamentos anteriores (Neumann et al., 2017). Essas formações estão associadas à evolução de um ambiente predominantemente lacustre para um ciclo flúvio-eólico.

Os vários níveis carbonáticos dispostos em pacotes de sedimentos pelíticos encontrados em afloramentos da Formação Aliança, marcam episódios de inundação do lago, com aumento da espessura de lâmina d'água, sedimentos em suspensão depositados e crescimento de atividade biológica. Nesse momento foram depositados os pacotes pelíticos. Esses episódios foram seguidos de momento de seca, onde a taxa de evaporação era superior à taxa de precipitação. Desse modo houve consequente atenuação da lâmina d'água com alta mortandade de organismos. Os níveis carbonáticos são bastante fossilíferos, marcando os momentos de seca e exposição subaérea desses lagos.

$\mathrm{O}$ estudo micropaleontológico feito com as carapaças e valvas desarticuladas de ostracodes do afloramento Modubim da Formação Aliança puderam destacar o Nível Carbonático 2 (MOD2) pela abundância de espécimes e boa preservação. $\mathrm{O}$ dente fóssil encontrado ainda na Formação Aliança corresponde a uma das espécies brasileiras do gênero Mawsonia. Sua ocorrência é um importante registro de um gênero extinto não marinho, restrito a paleoambientes continentais $\mathrm{e}$ estuarinos, que perdurou nas bacias cretáceas interiores do Nordeste e MeioNorte, a partir de sua primeira aparição na depressão afro-brasileira do Leste. Uma análise da morfologia dos icnofósseis da Formação Aliança sugere que as estruturas sedimentares vistas são marcas de repouso e de locomoção.

A Formação Sergi foi identificada em poucos locais, porém o suficiente para aparecer na escala adotada. Esta não aparecia originalmente na Folha Poço da Cruz. A formação compõe o pacote superior da sequência de Início de Rifte e possui rochas que marcam um momento flúvio-eólico. A sedimentação preservou estruturas importantes em que puderam ser identificadas estratificações cruzadas acanaladas com superfícies de reativação, além de plano-paralelas como também arenitos maciços. Além das análises estruturais a petrografia identificou esses dois sistemas agindo simultaneamente no mesmo ambiente de sedimentação.

O fragmento de tronco fóssil encontrado é um representante das madeiras com ocorrência similar às da Formação Missão Velha. Esses troncos são provenientes de uma cobertura arbórea mais extensa que se desenvolveu 
nas regiões um pouco mais altas do nordeste brasileiro naquela época, e que foi preservada por silicificação em diversas áreas marginais.

A Formação Candeias possui dimensões consideráveis e se concentra em boa parte da região central da área mapeada. Encontra-se bastante modificada antropicamente e, devido a sua semelhança com a Formação Aliança, para delimitá-la foram considerados os pontos com afloramentos em que se encontram os pacotes de arenitos esbranquiçados, fácies característica da Formação Candeias que não é encontrada na Formação Aliança.

Não foram encontrados registros que pudessem compreender o Grupo Ilhas.

A Formação São Sebastião também é abrangente na região sudoeste e chama atenção por suas formas arredondadas em morrotes e serras escarpadas. Mostra evidências da influência fluvial sobre um regime predominantemente eólico com depósitos de duna. Os depósitos quaternários são abundantes na área e associados a formações arenosas ou transportados por canais de fluxo de água intermitente.

\section{REFERÊNCIAS}

Arai, M. 2006. A grande elevação eustática do Mioceno e sua influência na origem do Grupo Barreiras. Geologia USP. Série Científica, v. 6, n. 2, p. 1-6.

Aragão, M.A.N.F. \& Peraro, A.A. 1994. Elementos estruturais do rifte Tucano/Jatobá. In: Simpósio sobre o Cretáceo do Brasil, 3, Rio Claro. UNESP, Boletim, pp. 161-165.

Assine, M. L. 1992. Análise Estratigráfica da Bacia do Araripe, Nordeste Do Brasil. Revista Brasileira de Geociências, v. 22, n. 3, p. 289-300.
Assine, M. L. 2007. Bacia do Araripe. Boletim de Geociências da PETROBRAS, v. 15 , n. 2, p. 371389.

Barreto, P. M. C. O. 1968. Paleozóico da Bacia do Jatobá. Boletim da Sociedade Brasileira de Geologia, v. 17 , n. 1, p. 29-45.

Braun, O.P.G. 1966. Estratigrafia dos Sedimentos da Parte Inferior da Região Nordeste do Brasil (Bacias do Tucano-Jatobá, Mirandiba e Araripe). Rio de Janeiro: DNPM/DGM, Boletim 236, 75 p.

Caixeta, J. M.; Bueno, G.V.; Magnavita, L.P.; Feijó, F.J. 1994. Bacias de Recôncavo, Tucano e Jatobá. Boletim de Geociências da Petrobras, v. 8, n. 1, p. 163-172.

Campos Neto, O. D. A., Lima, W. S., \& Cruz, F. G. 2007. Bacia de Sergipe-Alagoas. Boletim de Geociências da PETROBRAS, v. 15, n. 2, p. 405-415.

Caputo, M. V.; Crowell, J. C. 1985. Migration of glacial centers across Gondwana during Paleozoic Era. Geological Society of America Bulletin, v. 96, n. 8, p. 1020-1036.

Carvalho, R. R., Neumann, V. H., Fambrini, G. L., Assine, M. L., Vieira, M. M., da Rocha, D. E. G. A., \& Ramos, G. M. S. 2018. The basal siliciclastic SilurianDevonian Tacaratu formation of the Jatobá basin: Analysis of facies, provenance and palaeocurrents. Journal of South American Earth Sciences, v. 88, p. 94-106.

Costa, I. P.; Milhomem, P.S.; Carvalho, M.S. 2003. Bacias sedimentares brasileiras: Bacia de Jatobá. Aracaju: Fundação Paleontológica Phoenix, 2003. Disponível em: http://www.phoenix.org.br/Phoeni x53_Mai03.htm Acesso em: 02/01/2017.

Costa, I.P.; Bueno, G.V.; Milhomem, P.S.; Silva, H.S.L. E; Kosin, M.D. 
2007. Sub-bacia de Tucano Norte

e Bacia de Jatobá. Boletim de Geociências da Petrobras, v. 15, n. 2, p. 445-453.

Dantas, J.R.A. \& Lima-Filho, C.A. 2007.

Síntese da Geologia de Pernambuco. Disponível em: http://www.dnpm.gov.br/dstpe/tra balhos/Sint_PE/SintesePE_03.htm

Dunham, R. J. 1962. Classification of carbonate rocks according to depositional texture. Memoir AAPG, n.1, p. 108-121.

Fambrini, G. L., da Rocha, D. E. G. A., Oliveira, E. V., Jesuíno, P. C. L., de Menezes-Filho, J. A. B., Queiroz, R. G. B., \& Neumann, V. H. D. M. L. (2019). Análise Faciológica e Deposicional dos Depósitos Flúvio-Eólicos da Formação São Sebastião (Eocretáceo), Região de CamposIbimirim, Bacia de Jatobá, PE, Nordeste do Brasil. Geosciences = Geociências, 38(1), 1-31.

Fambrini, G.L.; Lemos, D.R.; Tesser Junior, S.; Araújo, J.T.; SilvaFilho, W.F.; Souza, B.Y.C.; Neumann, V.H.M.L. 2011. Estratigrafia, Arquitetura Deposicional e Faciologia da Formação Missão Velha (Neojurássico-Eocretáceo) na Área-Tipo, Bacia do Araripe, Nordeste do Brasil: Exemplo de Sedimentação de Estágio de Início de Rifte a Clímax de Rifte. Geologia USP, Série Cientifica, v. 11, n. 2, p. 55-87.

Fambrini, G.L.; Lima-Filho, M.F.; Costa, B.H.; Jesuino, P.C.L.; Tesser Junior, S. 2006. Sistemas fluviais entrelaçados de alta energia da Formação São Sebastião na Bacia de Jatobá, Nordeste do Brasil. In: Congresso Brasileiro de Geologia, 43. Aracaju: Sociedade Brasileira de Geologia. Anais... p. 289.
Fambrini, G.L.; Lima-Filho, M.; Tesser Junior, S; Costa, B.H.; Jesuino, P.C.L.; Valenca, L.M.M.; Neumann, V.H.M.L. 2007. Paleocorrentes fluviais da Formação São Sebastião, Bacia de Jatobá, NE do Brasil. In: Simpósio de Geologia do Nordeste, 22. Natal: Atas..., p. 45.

Fambrini, G.L.; Neumann, V.H.M.L.; Barros, C.L.; Agostinho, S.M.O.; Galm, P.C.; Menezes-Filho, J.A.B. 2013a. Análise estratigráfica da Formação Brejo Santo, Bacia do Araripe, Nordeste do Brasil: implicações paleogeográficas. Geologia USP. Série Científica, v. 13 , n. 4, p. 3-28.

Fambrini, G.L.; Neumann, V.H.M.L.; Lemos, D.R.; Araújo, J.T.; LimaFilho, M.F.; Silva-Filho, W.F. 2010. Stratigraphy and sedimentology of the Rift Initiation to Rift Climax stages of the Araripe Basin, Northeastern Brazil: new considerations. In: International Sedimentological Congress, 18., 2010, Mendoza, Argentina, Abstracts Volume... Mendoza: IAS/PETROBRAS, 2010, p. 333. 1 CD-ROM.

Fambrini, G.L.; Neumann, V.H.M.L.; Menezes-Filho, J.A.B.; Rocha, D.E.G.A.; Durval, L.G.; Jesuino, P.C.L. 2013b. Fácies e sistemas deposicionais da Formação São Sebastião (Eocretáceo), Bacia De Jatobá, PE: contribuição à evolução geológica do Rifte Recôncavo-Tucano-Jatobá, Nordeste Do Brasil. In: Simpósio de Geologia do Nordeste, 25. Gravatá: Conferências e resumos, Boletim 23, p. 176-177.

Ghignone, J. I. 1972. Ensaio de paleogeografia do Nordeste e as sequiências sedimentares. In: Congresso Brasileiro de Geologia. p. 21-28. 
Guzmán, J., Fambrini, G. L., Oliveira, E. V., \& Usma, C. D. 2015. Estratigrafia da Bacia de Jatobá: estado da arte. Estudos Geológicos,25, 1.

Horn, B. L. D., \& de Morais, D. M. F. 2016. First occurrence of the Salvador Formation in the Jatobá Basin (Pernambuco, Northeast Brazil): Facies characterization and depositional systems. Journal of South American Earth Sciences, 72, 25-37.

Kuchle, J. 2010. Análise tectonoestratigráfica de bacias rifte. Porto Alegre, 2010. Tese de Doutorado em Geociências - Instituto de Geociências, UFRGS.

Kuchle, J., dos Santos Scherer, C. M., Born, C. C., dos Santos Alvarenga, R., Adegas, F. 2011. A contribution to regional stratigraphic correlations of the Afro-Brazilian depression-The Dom João Stage (Brotas Group and equivalent units-Late Jurassic) in Northeastern Brazilian sedimentary basins. Journal of South American Earth Sciences, v. 31, n. 4, p. 358-371.

Lima-Filho, M.F.; Souza, G.M.; Silva Junior, R.P. 2009. Evolução do Graben do Puiú e o inicio do rifteamento na Bacia de Jatobá. In: XXII Simpósio Nacional de Estudos Tectônicos / VI International Symposium on Tectonics. Buzios: Anais... p.CDROM, resumo 0069-1-A-01.

Lima, R. P., Neumann, V. H. M. L., Rocha, D. E. G. A., Miranda, T. S., Gonçalves, L. R. L., Barbosa, J. A., ... \& Menezes-Filho, J. A. B. (2011). Sedimentologia e estratigrafia do paleolago aptiano da Bacia de Jatobá. In Congresso Brasileiro de Pesquisa e Desenvolvimento em Petróleo e Gás (Vol. 5).
Magnavita, L.P. \& Cupertino, J.A. 1987. Concepção atual sobre as bacias de Tucano e Jatobá, Nordeste do Brasil. Boletim de Geociências da Petrobras, v. 1, n. 2, p. 119-134.

Menezes Filho, N.R.; Santos, R.A.; Souza, J. 1988. Programa Levantamentos Geológicos Básicos do Brasil; carta geológica, carta metalogenética/previsional escala 1:100.000 (Folha SC.24-XC-V Santa Brígida). Estado da Bahia. Brasilia: DNPM/CPRM.

Miranda E. E. 2005. Brasil em Relevo. Campinas: Embrapa Monitoramento por Satélite. Disponível em: $<$ http://www.relevobr.cnpm.embr apa.br>. Acesso em: 05/01/2017

Neumann, V. H. D. M. L.; Miranda, T. S. D.; Figueiras, C. F. C.; Amaral, C. D. A. (2017). Geologia e Recursos Minerais da Folha Poço da Cruz, SC. 24-XA-VI: Estado de Pernambuco e Alagoas. CPRM.

Peraro, A.A. 1995. Caracterização sísmica do tectonismo transcorrente na Bacia do Jatobá. In: Congresso Internacional da Sociedade Brasileira de Geofísica. Rio de Janeiro: Anais... p.1-3.

Pires E. F. \& Guerra-Sommer M. 2010. Growth ring analysis of fossil coniferous woods from early cretaceous of Araripe Basin (Brazil), In: Academia Brasileira de Ciências, v. 83, n. 2, p. 409-423

Pereira, P. A.; Almeida, J. A. C.; Barreto, A. M. F. 2012. Paleoecologia Dos Bivalves E Braquiópodes Da Formação Inajá (Devoniano), Bacia Do Jatobá (PE), Brasil. Estudos Geológicos, v. 22, n. 1, p. 37-53.

Ponte, F.C. 1994. Extensão Paleogeografia da Bacia do Araripe no Mesocretáceo. In: IIISimpósio sobre o Cretáceo do Brasil, 131-135.

Ponte, F.C., Medeiro, R.A., Ponte Filho, F.C., 1997. Analise estratigráfica 
da Bacia do Araripe: Analise de sequência. In: II Simpósio sobre a bacia do Araripe e bacias interiores do Nordeste, Crato-CE

Ponte, F. C., \& Appi, C. J. (1990). Proposta de revisão da coluna litoestratigráfica da Bacia do Araripe. In Congresso Brasileiro de Geologia (Vol. 36, No. 1990, pp. 211-226).

Prosser, S. 1993. Rift-related linked depositional systems and their seismic expression. In: G.D. Williams \& A. Dobb (Eds.) Tectonics and Seismic Sequence Stratigraphy. Geological Society Special Publication, v. 71 ed., p. 35-66.

Queiroz, R.G.B., Fambrini, G.L., Neumann, V.H.M.L., 2017. Geologia da Área Centro-Leste da Folha Airi, Bacia de Jatobá, Nordeste do Brasil. Estudos Geológicos, v. 27(2), p. 82-109.

Rocha, D.E.G.A. \& Amaral, C.A. 2007. Caracterização Geologica e Geométrica dos Aquiferos (Meta B). In: Costa, W. D \& Feitosa, F. A. C (Coordenadores). Hidrogeologia da Bacia Sedimentar do Jatobá: Sistema Aqüífero Tacaratu/Inajá. Ministério de Minas e Energia Ministério da Ciênica e Tecnologia.

Rocha D.E.G.A. \& Leite J.F. 1999. Estudo hidrogeológico da Bacia do Jatobá-Geologia. Recife: CPRM.

Rocha, D.E.G.A. 2011. Caracterização do intervalo carbonático aptiano da Bacia do Jatobá, NE do Brasil. Tese de Doutorado em Geociências - Centro de
Tecnologia e Geociências, UFPE, $124 \mathrm{p}$.

Santos, C.F.; Cupertino, J.A.; Braga, J.A.E. 1990. Síntese sobre a geologia das bacias do Recôncavo, Tucano e Jatobá. In: Raja Gabaglia, G.P.; Milani, E.J. (coords.), Origem e Evolução de Bacias Sedimentares. Rio de Janeiro: Petrobras, p. 235-266

Schaller, H. 1969. Revisão estratigráfica da bacia de Sergipe/Alagoas. Boletim tecnico da Petrobrás, v. 12, n. 1, p. 21-86.

Sousa, K.; Oliveira, E.V.; Fran Barreto, A. M. 2013. Uma nova fauna do cretáceo continental da Bacia de Jatobá, Estado de Pernambuco, Brasil. Estudos Geológicos, v. 23, n. 1, p. 87-109.

SUDENE. 1969. Carta Topográfica Poço da Cruz, Folha SC.24-X-AVI em escala 1:100.000, Superintendência de Desenvolvimento do Nordeste (SUDENE) - Departamento de Recursos Naturais.

Valença, L. M. M.; Neumann, V. H. ; Mabesoone, J. M. 2003. An overwiew on CallovianCenomanian intracratonic basins of Northeast Brazil: Onshore stratiigraphic record of the opening of the southern Atlantic. Geologica Acta (Barcelona), Espanha, v. 1, n.3, p. 261-275.

Veras, J. D. D., Neumann, V. H., Valença, L. M. M., Madruga, M. M. D., \& Oliveira, S. R. (2017). Mapeamento geológico da porção sudoeste da folha Airi, Bacia de Jatobá, nordeste do Brasil. Estudos Geológicos, 27(1), 34-60. 